\title{
How Firm Performance Moderates the Effect of Changes in Status on Investor Perceptions: Additions and Deletions by the Dow Jones Sustainability Index
}

\author{
OLGA HAWN \\ Boston University, School of Management \\ E-mail: olga.hawn@gmail.com \\ AARON CHATTERJI \\ Duke University, The Fuqua School of Business \\ WILL MITCHELL \\ Duke University, The Fuqua School of Business and the University of Toronto, Rotman School of \\ Management
}

Version: March 28, 2014

\begin{abstract}
Organizational studies are only beginning to assess how firm value is affected when organizations gain or lose status. Drawing from the social evaluation literature, we suggest that the benefits and penalties that investors impose following changes in status will be moderated by firm performance. Using a large-scale financial event study of additions and deletions by the Dow Jones Sustainability Index to address potential endogeneity, we demonstrate that organizations with lower (current and expected) firm performance benefit more from gaining status and pay higher penalties for losing status. We contribute to the literature on status by extending the understanding of benefits and detriments of status to the status-seeking and status-holding organizations. We also extend the social evaluation and corporate social responsibility literatures by demonstrating that investors form their perceptions of sustainability through the lens of evaluating firm performance. Finally, we contribute to the neo-institutional literature by evaluating the role of this index as a private decentralized institution.
\end{abstract}

Key words: organizational status, investor perceptions, sustainability, firm performance

Acknowledgements: We appreciate comments from conference reviewers and participants at the 2010 Strategic Management Society, 2011 Academy of Management Meeting, 2011 IABS, 2011 Medici Summer School, 2011 Annual Strategy and the Business Environment Conference and 3rd Annual ARCS Conference, 2011 Transatlantic Doctoral Conference (LBS), Jorge Rivera and Robert Hoskisson at Bentley University's ESG Workshop on earlier drafts of this paper. Gerry McNamara provided particularly insightful suggestions. 


\section{Introduction}

Organizational status, defined "as an organization's publicly acknowledged social esteem and social worth relative to other organizations in a social hierarchy" (Chen et al. 2012: 300), is important for explaining organizational heterogeneity (Benjamin and Podolny 1999; Podolny 1993) and predicting organizational performance (Malter 2014; Parker and Hartley 1991; Washington and Zajac 2005; Zhao and Zhou 2011). Yet, the 2012 Organization Science special issue on status highlights the dearth of research on status dynamics at the organizational level, including the need to understand in greater depth how changes in status affect firm value for status-seeking and status-holding organizations (Chen et al. 2012). This study examines how changes in organizational status affect investor perceptions of firm value and, in turn, how firm performance may moderate the benefits and detriments of status gain or loss for status-seeking and status-holding organizations. Drawing from the social evaluation literature, we argue that high performers will not benefit or lose as much as underperformers when they gain or lose status.

We focus on prestige-based status attained through "prosocial behavior and association with highstatus others who enjoy social regard" (Chen et al. 2012: 300). We examine membership in the Dow Jones Sustainability Index (DJSI), which reviews its components annually by adding new members and dropping existing members from its list if they do not satisfy their social, environmental, and corporate governance criteria - these activities define prosocial behavior of focal firms. Every year 2,500 large organizations can seek sustainability status through membership in this index by filling out the DJSI survey and undergoing the DJSI review. The "best-in-class" methodology ensures that organizations represented in the index are the top $10 \%$ leaders in sustainability within each industry. Hence, firms that get added to the index gain prestige-based status and firms that get dropped lose status relative to their direct competitors (i.e., firms within their social hierarchy).

We examine investor perceptions of these changes in status through a financial event study of stock market reactions. Such reactions are rewards or penalties that affect future organizational decisions; hence, market reactions are important short-term outcomes with long-term effects. Because our focus is on the event of additions and deletions from the DJSI, this methodology allows us to capture the direct benefits and detriments to gaining or losing status. Moreover, as long as market reactions reflect available 
information ("efficient markets hypothesis"), this method helps address endogeneity regarding the statusreputation/quality-performance relationship. We argue that firm performance moderates the effects of status gain or loss due to investors' social evaluation process: while investors often have uncertainty about how to assess such effects, indicators of current and expected firm performance help them evaluate the value of status signals. In doing so, we extend the literature on the formation of investor perceptions, in particular, how the thought world of "Wall Street" - investors and market analysts - may be different from that of "Main Street" - more general society (Lamin and Zaheer 2012).

A recent study by Lamin and Zaheer (2012) shows that Wall Street and Main Street often perceive organizational actions quite differently, suggesting that these worlds operate by separate moralities in which Main Street appears to privilege fairness as a core value, whereas Wall Street tends to place greater relative weight on profits. We build on this idea by differentiating between these audiences; in turn, we reconcile the tension between more general society and investors by focusing on sustainability as a source of status. Sustainability, corporate social responsibility (CSR), corporate citizenship, and other terms generally describe social, environmental, and governance activities that affect a broad range of stakeholders (Gardberg and Fombrun 2006); these organizational actions emerge in response to increasing pressure from general society (Campbell 2007; Zhang and Luo 2013). By providing external validation and evaluation of such activities to the market, social indices such as FTSE4Good, the KLD, and the DJSI bridge the worlds of Wall Street and Main Street.

Our argument contributes to organizational scholarship in three ways. First, we extend the literature on status dynamics by examining their performance implications at the level of organizations, showing that investors may react differently to status gain or loss based on firm performance. Second, we contribute to social evaluation studies and the growing literature on when CSR pays by arguing that it depends on the evaluation by market actors. Third, we contribute to the neo-institutional literature by examining the role of the DJSI as a private decentralized institution (King et al. 2005).

In turn, the empirical setting provides two contributions. First, by testing our argument in a financial event study that examines the effect of changes in status, we address the potential endogeneity 
problem arising from the relationship with firms' financial performance in many CSR studies (Margolis et al. 2007) as well as in the relationship between status and quality/reputation (Simcoe and Waguespack 2011). Second, through the analyses as well as multiple interviews with market actors, we advance recent CSR studies on the impact of additions and deletions from a social index (Consolandi et al. 2009; Lackmann et al. 2012; Robinson et al. 2011), even in light of prior financial performance and CSR reputation (Doh et al. 2010); these studies find inconsistent results (Michlik and Rubash 2011) and do not clearly outline when and why CSR matters. We explain this relationship, finding consistent impact for additions and deletions, by analyzing the processes by which investor perceptions are formed.

Overall, we demonstrate that even though additions to social indices articulate gaining social status and deletions indicate losing social status, investors interpret the events differently for firms with different levels of performance. Firms with higher current and expected performance characteristics have less to gain from increased social status and, in turn, have less to lose from losing social status.

\section{Impact of Status on Performance}

Most prior research on the effect of status on performance has been conducted at the individual level. For example, in the context of NASCAR and the PGA, Bothner, Kim, and Smith (2012) show that status can be both an asset and a liability, suggesting a curvilinear effect of status on individual performance. Similarly, Bendersky and Shah (2012) examine the performance effects of gaining or losing status in one's group over time, finding that (1) higher status of individuals at the end of the group's life is associated with higher performance; (2) performance of individuals who gain or lose status over time does not correspond to their final status positions, such that those who gain status - including those who eventually gain high status - perform worse than those who maintain high-status positions throughout, and perform no better than those in stable low-status positions throughout; and (3) individuals who lose status over time actually perform as well as those who maintain high status. However, there is little research on this relationship at the organizational level, which offers greater complications due to differences in relevant evaluators. We join the debate by focusing on conditions (firm performance) that moderate the effect of status on investor perceptions of organizational value. 
Most recent studies on the relationship between status and performance at individual and organizational levels highlight the importance of quality and/or reputation to status in accounting for performance heterogeneity. Scholars argue that causal relationships between status and performance require methods that can disentangle potentially-endogenous links between status and quality/reputation (Azoulay et al. 2014; Malter 2014; Simcoe and Waguespack 2011). For example, Malter (2014) assesses returns to status independent of quality and reputation by using French wine (status) classifications that have not changed in more than 150 years, utilizing instrumental variable and matching. Simcoe and Waguespack (2011) use a natural experiment that exploits random variance in status signals through a difference-in-differences approach. Azoulay, Stuart, and Wang (2014) use a matched sample of similar products, with one belonging to a high-status producer and the other to a potential contender for status, and compare the outcomes of these products before the status was granted to a producer. These studies suggest that we need to ensure that our study not only conceptually separates quality/reputation from performance and status but also that it has a convincing research design. Therefore, our conceptual development and empirical method are interdependent and warrant concurrent discussion.

\section{The DJSI and Social Status}

Let us begin by defining status and describing the mechanism by which status is acquired and lost in our setting. The conception of status is compatible with the formal economic understanding of signals (Podolny 2005). A signal is any observable indicator of quality that meets two criteria: (1) the indicator must be at least partially manipulable by the actor, and (2) the marginal cost or difficulty of obtaining the indicator must be nonzero and inversely correlated with the actor's level of quality (Spence 1973). In our setting, membership in the DJSI is an important signal of sustainability status because its attainment is partially within a company's control (see Appendix A), and because it is more difficult for those who lack sustainability to be added to the index (see Appendix B).

Every year 2,500 large firms are invited to participate in a survey to become members in the DJSI. Conceptually, by becoming a member, organizations receive a token of sustainability status, join an elite club with exclusive membership, and potentially administer a shock to their perception in the market. 
Due to privacy concerns, we do not know who decides to undergo the DJSI evaluation. This could cause a selection bias if we were concerned with the universe rather than status-seeking and status-holding organizations, and could become a limitation in our research if we knew that only high-quality highreputation firms seek DJSI membership. However, the fact that there is an element of uncertainty in who seeks this status adds randomness to the quality and reputation orders within our sample: a state in which there is a distorted representation of the quality and reputation orders is what we need to discern the effect of status from those of quality or reputation (Malter 2014). What we do know in our context is who sends the signal, receives a shock, obtains social status by being added to the index, and who loses status by being dropped: this is necessary and sufficient information for examining the effect of status on investor perceptions independent of quality/reputation.

The efficient market hypothesis assumes that existing share prices incorporate and reflect all available relevant information. Therefore, existing perceptions of quality and/or reputation attributed to the organizations in our sample will already be reflected in the stock price and should not affect market reactions to signals of changes in status. We will argue that a relevant factor for investors to change their perceptions following changes in status will be firm performance: investors will review the changes in social status in light of familiar financial indicators they trust to make a judgment. Empirically, given that a) we focus on the event of changes in social status, b) our main variable of interest is firm performance, and c) the dependent variable is investor perceptions of firm value, we depart from more traditional studies in the organizational literature. Nonetheless, this method helps us investigate important outcomes of organizational status independent of quality/reputation as we described above.

We examined the criteria by which DJSI evaluates organizations to ensure that the dynamic feedback loop that might render status an artificial correlate of performance (Azoulay et al. 2014) does not exist in our setting. We ensure that changes in status are not driven by firm performance (see Appendix B) and that DJSI evaluation of status-seeking firms does not reflect financial bias and is important to many actors by itself (see Appendix A). Moreover, since our dependent variable reflects a focused (i.e., over a narrow event window) comparison of the stock price of the DJSI firm with that of its 
direct competitors (i.e., firms in its beta-portfolio), without requiring other matching, we gain a relevant match of the DJSI firm with the firms in its social hierarchy (i.e., potential contenders for sustainability status). These nuances ensure appropriate research design and conceptual distinctions between status, quality/reputation, and performance.

\section{Investor Perceptions of Changes in Social Status}

Prior studies highlight that some uncertainty in the context is required for status signals to carry useful information (Azoulay et al. 2014; Podolny 1993; Simcoe and Waguespack 2011). In this section we discuss how uncertainty regarding firms' sustainability efforts affects investor perceptions. First, we establish that there is uncertainty about how to judge organizational sustainability. Second, we discuss how investors perceive signals about sustainability differently than do other audiences. Lastly, we develop hypotheses on the effect of firm performance on investor perceptions of changes in social status.

There are several reasons why uncertainty prevails in the field of sustainability. First, definitions of CSR are variable and malleable; moreover, while most CSR action is self-imposed or voluntary, some governments have begun to look to legislation to encourage CSR (Orlitzky 2013). In turn, regulatory uncertainty around CSR and uncertainty as to what qualifies as voluntary or legally mandated social activities (e.g., fair wages and working conditions in all operations at home and abroad) make it hard for investors to judge the value of CSR investment. Second, reliable social indicators often are difficult to produce and, even when they exist, are hard to interpret (Chatterji et al. 2009). A firm's own executives are often uncertain about the implications of social indicators: interpreting the impact of environmental actions, for instance, is highly uncertain not only for executives but also for engineers who undertake them, let alone for investors. Third, due to increasing institutional pressures and an ever growing number of companies worldwide that engage in CSR, this context is inherently prone to decoupling (i.e., engagement in symbolic and/or substantive actions) (Weaver et al. 1999). Being able to distinguish between symbolic and substantive organizational actions in the field of CSR raises levels of uncertainty for investors. Finally, because external stakeholders, including potential and actual investors, have less information about organizational processes and outcomes related to CSR than business executives, CSR 
signals are subject to information asymmetry that may raise the level of noise (Orlitzky 2013) and uncertainty in capital markets. Before analyzing how investors make sense of this noise, we need to discuss how they may perceive CSR information differently than other critical organizational audiences.

The social evaluation literature (for the most recent overview see Bitektine 2011) describes an evaluator's perspective by distinguishing among different questions about an organization that different evaluators care about. However, even when different audiences seek to answer the same question about an organization, they may have different assessments. For example, when evaluating organizational responses to challenges of legitimacy, Wall Street varies from Main Street (Lamin and Zaheer 2012: Table 3). The differences arise not only from cognitive mechanisms but also from different roles that different evaluators play in the market. For example, when evaluators face the same problem categorizing an organization (e.g., the presence of organizational ambiguity), market-takers (consumers) may punish but market-makers (venture capitalists) may reward ambiguous labels on organizations (Pontikes 2012).

In our context, it is helpful to distinguish between market and non-market actors to highlight the different roles that different evaluators play in assessing organizational sustainability. The distinction is consistent with the long-standing debate in the CSR literature rooted in the tension between business and society, whereby Friedman (1970) claims that the main responsibility of business lies in meeting shareholders' financial expectations, while Freeman (1984) highlights a much broader set of relevant stakeholders (e.g., employees, customers, partners, and communities) and argues that, by meeting stakeholder demands, organizations can become more successful.

The difference between market and non-market actors rests in the nature of intermediaries as well as characteristics of firms' interactions with the environment (Baron 1995). Market interactions are intermediated by markets or private agreements, typically voluntary in nature such as economic transactions and the exchange of property, that create value by improving economic performance. Market actors include executives, investors, analysts, brokers, and others who actively assess an organization's economic activity (Zuckerman 1999). Non-market interactions are intermediated by government, media, public institutions, and other stakeholders, voluntary or involuntary in nature, that create value by 
improving multiple dimensions of performance (Baron 1995; Wood 1991). Non-market actors include regulators, employees, non-governmental organizations, and the local community who rely on a wider system of criteria when evaluating organizations (Bonardi et al. 2005).

The main difference in organizational evaluations by market and non-market actors stems from differences in their value systems: while general society may value human capital development, health and safety, and environmental sustainability (Delmas and Toffel 2008; Terlaak and King 2006), investors often have stronger interests in the future viability of a firm as an economic agent (Cohen and Dean 2005; Friedman 1970; Hirsch 1975; Pfeffer 1981; Westphal and Zajac 1998). As members of general society, market actors do care about CSR, including the social impact of firms' economic activity, and vice versa, society will care about financial performance of the firm as it relates to its viability; however, when evaluating organizations Wall Street and Main Street tend to emphasize different criteria (Hybels 1995; Lamin and Zaheer 2012; White 2001).

The main reason for the different criteria, the key sources of differences in their judgment, lie in frames of reference that arise from market actors' intendedly rational cognitive maps, objective data, and empirical reality testing (Shrivastava 1987). The emphasis on rationality, objectivity, and empiricism enables management to understand and defend the organization's performance, regardless of its underlying social values (Ashforth and Gibbs 1990). Objective data provide market actors with a concrete basis for judgment of the company as an investment target, whereby market actors demonstrate their endorsement of an organization through investment, loans, and ongoing support by analyst recommendations and ratings. As we found in multiple interviews during this research, investors value the future financial viability of the firm, where relevant indicators include historical track records and current firm performance measures, as well as credit quality and forecasts of future growth.

To be able to make judgments about organizations, investors expect objective financial outcomes, especially profitability (Hirsch 1975; Pfeffer 1981). Profitability assures investors that a firm is viable and worth supporting. In turn, investors can change their perceptions based on more subjective indicators of performance such as innovativeness, cost effectiveness, expected growth, and technical efficiency, which 
shape expectations about future firm performance (Love and Kraatz 2009; Shapiro 1982). Such indicators influence investors' and other market actors' perception of a firm directly as well as indirectly via analysts' ratings and recommendations (Westphal and Clement 2008). As a result of a record of success and expectations of future financial viability, organizations gain support from the financial market. Thus, investor perceptions are formed through the lens of tangible indicators of firm performance.

\section{Hypotheses}

Let us consider how firm performance affects the degree to which investor perceptions change with gaining or losing social status. We do not predict a main effect of changes in social status, expecting that additions will generate market rewards and deletions will generate penalties - based on other empirical studies of the main effects in the context of additions and deletions from socially responsible indices (Cheung 2011; Doh et al. 2010). The key mechanism relevant for our argument is the incremental economic impact of gaining or losing social status for firms with greater or lesser firm performance.

First, let us consider the incremental impact of gaining social status. Greater firm performance, at least in countries with active financial markets, labor markets, and other elements of business infrastructure, reflects competitive advantages. So in addition to their ability to support existing activities, firms with greater performance will be able to garner resources to reinforce their business or to expand into new activities. Hence, gaining social status may provide only limited incremental value, because the firms can already obtain most resources that they need. By contrast, firms with lower firm performance often struggle to gain access to new resources. In such cases, gaining social status may provide an alternative route to attracting investment, personnel, regulatory support, and other resources needed to sustain existing operations and develop new activities that they would otherwise struggle to obtain by relying solely on their market position. Therefore, investors will expect gains in social status to provide greater incremental economic benefits for firms with lower firm performance.

Hypothesis 1 (H1): The higher the firm performance, the lower the financial market rewards for gaining status.

Second, let us consider the incremental impact of losing social status. Firms with lower levels of performance suffer most if they lose status. The instrumental financial logic suggests that firms with 
strong firm performance will attract resources in any case. Investors will often be willing to support a high-performance firm even if it visibly undertakes actions that do not align with social norms (Ruef and Scott 1998; Singh et al. 1986). For instance, despite increasing social disapproval cigarette companies, long attracted investment - even from health professionals - because their higher levels of profitability and growth substituted for social standing. Similarly, energy and pharmaceutical companies face regular criticisms of their environmental practices, political lobbying, questionable engagements in developing markets, and other socially dubious activities. Indeed, energy and pharmaceutical firms consistently fall near the bottom of social reputation indices (e.g., in the tail of the annual Gallup poll of industry image from 2001 through 2013). Nonetheless, many energy and pharmaceutical sector firms have strong financial performance and, as a consequence, are viewed positively by investors.

In turn, such companies easily attract investment and weather challenges to their social status that would otherwise severely damage firms with worse performance. In an extreme case, BP recently suffered massive losses in social status as a result of the Gulf oil disaster. However, while it also lost major economic value directly after the spill, the company continues to operate; in 2011, BP announced that it would pay its first dividend since the spill and planned to increase its total investment by $\$ 2$ billion (Werdigier 2011, February 1). With this in mind, BP will survive and attract new investment in the future. Similarly, the pharmaceutical firm Merck continues to prosper despite major losses in social status following its withdrawal of the anti-pain drug Vioxx in 2004 due to cardiovascular problems. In contrast, companies with worse firm performance would not have these survival and recovery chances. Hence, we expect firms with higher performance to pay lower market penalties for losing their social status.

Hypothesis 2 (H2): The higher the firm performance, the lower the financial market penalties for losing status.

In sum, the hypotheses propose that firm performance moderates how changes in social status affect investor perceptions. This effect between social status and firm performance is important to examine for strategic and theoretical reasons. We now turn to our empirical setting, focusing on market reaction to addition and deletion from indices of socially responsible activity. 


\section{Data and Methodology DJSI and Social Status}

Status measures or signals tend to be context-specific (Podolny 1993): prior studies have considered the ability to speak English for French employees working in a global organization (Neeley 2013), the invitation to participate in NCAA tournament for universities (Washington and Zajac 2005), Financial World's widely publicized CEO of the Year contest for managers (Graffin et al. 2008), analyst rankings for organizations (Phillips and Zuckerman 2001) and other ratings within various empirical settings (Bothner et al. 2012). We use the context of social indices that rate and certify socially (ir)responsible companies by adding them to or dropping them from their lists.

We focus on the DJSI, a key social index increasingly viewed as a mechanism for gaining social status, for four reasons. First, DJSI provides international coverage in both developed and emerging markets since 1999. Second, DJSI is more publicly visible and is familiar to most experts (e.g., while the commonly-used KLD licenses their index for a fee and does not openly disclose its changes to the index, the DJSI publishes press releases and reveals the list, including additions and deletions, on its website and to its licensees). Third, DJSI has been recognized as "the most rigorous in terms of the number of questions and depth of information requested" (UNEPFI 2008) as well as one of the most credible indices (SustainAbility 2012). Fourth, many fund managers globally recognize and value the DJSI: in 2010, DJSI licensees included 88 global institutions in 16 countries with more than $\$ 8$ billion total investment in the financial products in the index ${ }^{1}$; in comparison, KLD's list included 11 licensees.

To further assess the DJSI as a meaningful mechanism for signaling social status, we undertook four procedures. First, we examined media and academic attention to CSR, sustainability, and the DJSI. Second, we considered the criteria for the addition to DJSI and why it is a relevant signal of social status. Third, we conducted an archival review of reactions to the addition to DJSI by about twenty North American and European companies. Fourth, we interviewed analysts on the importance of social indices in their evaluation. Appendix A reports the results of this assessment.

\footnotetext{
${ }^{1}$ http://www.sustainability-index.com/07_htmle/other/faq.html
} 


\section{Methods and Data}

A meta-analysis on the link between corporate social and financial performance (Margolis et al. 2007) recommended that future studies meet four criteria. First, data about firms' CSR should consist of reliable measures such as quantifiable outputs or third-party audits, using assessment processes that are clear and open to validation. DJSI meets this criterion because it uses an independent organization to collect and verify company and non-company data, as well as undertaking an annual audit of each firm on the index. Second, studies must control for factors such as geographic location, industry, risk, size, R\&D spending, and advertising expenditures (McWilliams and Siegel 2000). Our dependent variable, beta excess returns, inherently controls for risk by representing a difference between the asset's return and the return on a reference asset that is assumed to be riskless (Campbell et al. 2007); we also include multiple controls. Third, the direction of causality needs to be theoretically articulated and empirically assessed at different time periods. The event study methodology addresses this concern. Finally, the mechanism by which CSR affects financial performance needs to be articulated. This paper develops a perspective on this relationship by identifying the evaluation process that generates investor perceptions.

We use a financial event study with an original dataset of additions and deletions from the DJSI World. The event study measures the effect of an unanticipated event on stock prices. The abnormal returns reflect the stock market's reaction to the arrival of new information, where the abnormal returns are calculated by subtracting the expected return for the stock from its actual return (McWilliams and Siegel 1997). If significant, abnormal returns indicate the average (causal) effect of the event on the value of the firm; that is, the presence of significant abnormal returns allows the researcher to infer that the event had a significant impact on firm value. Inferring significance relies on two assumptions: first, events were unanticipated; second, no confounding effects occurred during the event window. This method helps researchers avoid the use of accounting-based measures of profit, which are weak indicators of actual performance and connect only weakly to individual events.

The event of additions and deletions from DJSI World occurs annually. While the announcement of changes is anticipated, the event of addition or deletion of particular companies is unexpected (more 
information can be found http://www.sustainability-indexes.com/images/djsi-world-guidebook_tcm1071337244.pdf). We control for confounding events with media articles described below and drop events if the firm made other information disclosures surrounding the event date that might confound the results.

For the event study method to be reliable, the DJSI must send a significant signal about CSR to the market. Fowler and Hope (2007) identify three criteria for such a signal. First, the news must be announced through sources other than the company itself: the SAM Group publishes annual releases of the index changes in press and on their website. Second, the audit of social, environmental, and corporate governance performance must be conducted by a third party: the DJSI uses independent third parties (the SAM Group and Evalueserve) to examine all three performance indicators simultaneously. Third, the CSR engagement needs to be so substantial that it makes the company a leader in its industry; the DJSI selects companies based on a "best-in-class" approach that seeks to identify the best companies in each industry sector. This is consistent with the status literature in identifying status as a positional good (Hirsch 1977): there can only be a few at the top of a given status hierarchy (Podolny 2005).

The process by which DJSI World is compiled every year starts with an invitation to the 2,500 largest companies (by market capitalization) to participate in an assessment (by sending them a survey as well as conducting stakeholder media analysis throughout the year by third parties). Companies are then ranked within each industry by industry-specific as well as general criteria on corporate governance, social, and environmental dimensions. Only those industry sectors where the highest ranked company has a Total Sustainability Score of at least $40 \%$ of the maximum score (relative to the best scoring company in the eligible universe) are eligible for the DJSI World. Other sectors - and their associated companies are deemed ineligible and are eliminated from the selection process. From each eligible industry sector, only companies with a Total Sustainability Score of at least half of the highest ranked company in the existing DJSI universe are eligible for the inclusion into the DJSI World. Other companies are deemed ineligible and are eliminated from the review process. This is how only sustainability leaders in each eligible industry end up on the index (DJSI does not exclude any industries from the evaluation); in turn, if they lost their leadership position to its peers in the industry (or their industry sector experienced some 
crisis and as a result saw a decrease in CSR), they are dropped. There is no limit to the number of slots in the index but the comparative analyses of the best in class (in the industry sector) eliminate "unworthy" companies from the "worthy" ones.

We used an event study because it isolates investors' reaction as a mechanism for associating CSR and financial performance (Margolis et al. 2007). Given the specifics of DJSI World and our approach to the study, we did not face a national bias or confounding events, for three reasons. First, our sample included companies from fourteen countries (Australia, Brazil, Canada, Chile, China, Germany, France, Japan, South Africa, South Korea, Spain, Taiwan, the U.S.A., and the U.K.). Second, we excluded events if the firm made other information disclosures surrounding the event date that might confound the results. Third, we undertook a Lexis-Nexis search for potential events that may have affected investors' decisions during the fourteen months before the announcement and one week before the announcement (the former period is when the DJSI is evaluating firms for addition or deletion, while the latter targets a more narrow period of time in which confounding events to the immediate reaction of investors could have taken place).

We identified three prior empirical studies of performance that examined the DJSI. Two of them evaluated determinants of adding European firms from 1998-2004 (López et al. 2007; Ziegler and Schroder 2010), relying on accounting measures of performance; the third used U.S. stocks in 20022008, and an event study without controls for firm or industry characteristics (Cheung 2011); all three studies find inconclusive results. Our study, in addition to undertaking a more refined methodology with beta excess returns as a measure of financial performance, uses a more extensive timeframe (1999-2007) and encompasses a larger number of countries.

Overall, the DJSI as a source of data suited the event study due to its global reach, brand visibility, yearly review, continuous monitoring of companies, openness of information, consistent methodology, and availability for licensing. Between 1999 and 2007, the DJSI added about 500 firms and deleted about 300 firms. Due to data availability on CSRP (which provides data for firms listed on NYSE and AMEX) and exclusion of confounding events, our final dataset includes 268 addition events that 
listed 216 companies (companies that were added twice were added in non-consecutive years) and 150 deletion events that delisted 133 companies; $58 \%$ of the firms were U.S.-based. This sample is substantially larger than in previous studies. By checking the assumptions of event studies, we assured the quality of the data and implementation of the study. Appendix B addresses potential endogeneity concerns as to the drivers of additions and deletions.

\section{Measures}

Investor perception of the firm. Investor perceptions are reflected in the market valuation of the firm (Lamin and Zaheer 2012; McWilliams and Siegel 1997), operationalized as the cumulative abnormal daily stock returns observed after the event of addition or deletion to the DJSI. Beta Excess Returns (BER) comes from the Daily Stock file of The Center for Research in Security Prices (CRSP): it is the excess return of a stock issue less the average return of all issues in its beta-portfolio on each trading date, calculated using NYSE and AMEX data. We use BER as a dependent variable because it inherently controls for risk and compares the focal company to its competitors in the market (i.e. its beta-portfolio).

We computed beta excess returns over a narrow two-day event window beginning one day after the announcement of DJSI changes (+1) and continuing for one additional day (+2); we tested our models separately on days +1 and +2 , finding consistent results. Using such a narrow event window that begins after a change to the index has been announced allows us to capture the market's reaction to the event, as new information is quickly absorbed by the market and gets reflected in stock price changes.

Changes in status. As we noted above, we use the event of addition to and deletion from the DJSI to indicate gaining and losing status.

Firm performance. We reviewed the academic literature and interviewed analysts with experience in global financial markets in New York, London, and Moscow (Bloomberg, investment banks, and financial research firms) to determine which firm performance indicators market actors use when they assess firms. We found that future financial viability of the firm is important in their evaluation process; to assess it the analysts identified two types of indicators of firm performance: current and expected.

Current measures of firm performance help form perceptions of the future financial viability of 
the firm, which is critical to investors. Relevant measures include profitability, liquidity, and other ratios that assess profitability. The interviews highlighted multiple ways of constructing perceptions of future viability of the firm, so that there is no one best indicator; instead, one needs to evaluate the impact of multiple inputs. Therefore, we assess the impact of six indicators that measure Current Firm Performance: (1) earnings before income and tax margin (EBIT margin), (2) earnings from continuous operations margin (ECO margin), (3) net income margin (return on sales, i.e., ROS), (4) return on assets (ROA), (5) return on equity (ROE), and (6) return on capital (ROC). We used a composite measure of standardized values (z-transformations: mean=0, s.d. $=1$ ) of the six ratios as our primary measure.

As we note below, we assessed other potential indicators in sensitivity analysis. The data on financial performance comes from Capital IQ, which covers about 88,000 companies globally with over 5,000 financial data items. The six ratios are percentages, which makes it possible to compare across them and form a composite measure of all current indicators. Table 1a reports descriptive statistics for standardized values of the items. Appendix $\mathrm{C}$ shows that the six individual measures had consistent influence (with somewhat varying significance) on the impact of addition and deletion by the DJSI.

$* * * * * * * * * *$ Tables 1a and 1b about here $* * * * * * * * * *$

The analysts also identified expected performance indicators that rest in third-party assessments, recommendations, and company ratings as key in evaluation process by investors. They include credit ratings by Moody's, Standard \& Poor's, Fitch, and analyst recommendations to buy, hold, or sell a stock. These measures generally include market research, industry reports, and industry rankings that demonstrate firms' "ability to deliver future maintainable/sustainable earnings." Our interviewees suggested that such subjective third-party sources primarily complement their own assessments of objective data - indeed, they noted that they commonly search for a rationale within the subjective data that will support their own prior assessments. In our event study, we assess the impact of analyst recommendations "to buy" a firm's stock during either of the two days prior to the event of addition or deletion by the DJSI - this allows us to capture their effect on immediate investor reactions as any new information is quickly absorbed by the market. We call this measure Expected Firm Performance. 
The data on analyst recommendations comes from First Call Analyst Recommendations database, where the contributing analysts represent major international research firms, regional firms, and boutiques. The database provides broad coverage and local expertise to over 50,000 institutional investors and brokerage firms worldwide. We searched for analyst recommendations to buy (which should strengthen investor's perception of future viability of the firm) during a short event window -1 or -2 days before the DJSI announcement. If more than one analyst made recommendations on the same day, we calculated the average between them: analyst recommendations range from 1 (Strong Buy) to 5 (Strong Sell); our measure of the recommendation to buy was coded as 1 when analysts' recommendations were lower than 2.5 and 0 otherwise. Table $1 \mathrm{~b}$ reports descriptive statistics for the variables, including the control variables that we describe below.

We considered other potential measures that relied on long-term (historic) indicators. First, we examined several measures of longer-term profitability and growth. Then, we considered Standard \& Poor's annual ranking of firm quality and credit rating in the year of the announcement, as well as average analyst recommendations over the year. These longer-term measures were not significant. The insignificant impact of the longer-term indicators was consistent with our interviews: the analysts said that their evaluations focus on information from the past two to three months, so that the effect of annual ratings and longer-term financial performance will tend to have little influence on their evaluation.

Control variables. The analysis included industry dummies based on the DJSI classification (consumer, industrial, financial, and natural resources), dummy variables for headquarters location (North America, Europe, and Other), variables for negative and positive news during 14 months and 1 week before the DJSI announcement, and organizational size (log of the number of employees). Industry is relevant because the closer the product is to the end customer, such as the consumer industry, the stronger investor preferences might be for CSR (Porter and Kramer 2006) and, thus, the higher the gains or losses from inclusion or exclusion from the DJSI. Geographic location of a company can also affect the economic value attached to CSR; in particular, the European Union has a longer history of corporate social engagement and stronger regulations (Waddock 2008), so investors might particularly welcome the 
addition to the index for firms from these countries or, instead, might simply take CSR for granted.

The variables for prior positive and negative news reflect the need for the listing event to provide new information about CSR. The less long- or short-term prior information there is about a firm's CSR activities, the higher the impact that the event may have on the investors. We controlled for confounding events with a Lexis-Nexis search for potential events that may have affected investors' perceptions. Our search included major world publications in two periods. For the period of fourteen months before the event, we sought headlines that referred to the company with the keywords "environment," "fine," "illegal," and/or "sue" within 40 words from the company name. For the period of one week before the announcement, we sought headlines that included the company name, with the general words "good," "bad," "positive," "negative," or "outstanding" within 20 words from the name of the firm. The former period is when the DJSI is evaluating firms for addition or deletion, while the latter targets a narrow period of time in which confounding events to the immediate reaction of investors could have taken place. We used these search terms for the fourteen months window to capture any news that might have helped investors predict the addition or deletion from the DJSI, and for the one-week period to assess the extent of the surprise reaction that investors might have to the changes in status. While conducting the LexisNexis search, we were looking for mentions of CSR-related activities presented in either positive or negative light. We then coded these mentions in the press as four separate count variables: positive/negative press 14 months and positive/negative press one week before the announcement.

We also use organizational size as a control variable in some models. Organizational size could reflect status because it may provide power in market activities such as in obtaining a contract with a local supplier, but it may also be a source of vulnerability in non-market activities because larger and more visible organizations are more likely to be attacked by interest groups (Kostova and Zaheer 1999). Including or excluding size did not affect our predicted effects in either the addition or deletion models. Size has a significant effect on its own in the case of additions to the DJSI. By contrast, size did not affect market reaction to deletions when we include a constant term in the deletion models, where the constant reflects the main effect of deletion. We exclude the insignificant size variable from the deletion models 
because it tended to overlap with the negative main effect of the constant term. Appendix D reports sensitivity analyses with and without organizational size, as well as with and without the constant term. We will discuss these sensitivity analyses following the main results, along with other robustness checks.

\section{Results}

Table 2 reports the results. Model 1 and Model 5 report baseline models for addition (268 cases) and deletion (150 cases, including 11 for which we lacked data when the DJSI first added them to the list). The effect of the event of addition on investor perceptions overall is positive (the constant term $\alpha=$ 0.0367, $\mathrm{p}<0.05)$, while the effect of deletion is negative $(\alpha=-0.0103, \mathrm{p}<0.10)$, consistent with prior work (Cheung 2011; Doh et al. 2010). Given that the coefficients on the constant show investor perceptions when all other variables are equal to zero, we also calculated the returns using the mean value for interval variables and the reference category for categorical variables. Addition generated positive return of $0.1 \%$ while deletion resulted in negative return of $1 \%$ : this confirms that gaining status may pay off at least moderately, while losing status is generally perceived as substantially negative by investors. In the addition model, greater size confers less benefit $(\beta=-0.0034, \mathrm{p}<0.05)$, while the service sector gains more benefit relative to the other industries (most significantly in comparison to the consumer sector). In the deletion model, the resource sector suffers less $(\beta=0.0194, \mathrm{p}<0.05)$, while firms with negative press during the week prior to the event suffer more $(\beta=-0.0092, \mathrm{p}<0.01)$.

\section{$* * * * * * * * * *$ Table 2 about here $* * * * * * * * * *$}

The results in Models 2-4 of Table 2 support Hypothesis 1. Model 2 uses the aggregate measure of Current Firm Performance, finding support for H1 $(\beta=-0.0061, \mathrm{p}<0.01)$. Model 3 uses measure of Expected Firm Performance, also finding support for $\mathrm{H} 1(\beta=-0.0279, \mathrm{p}<0.01)$. Model $4 \mathrm{a}$ includes the effects of both measures of firm performance, once again finding support for H1 with consistent results for Current and Expected Firm Performance $(\beta=-0.0058, p<0.05 ; \beta=-0.0268 p<0.01)$. Model $4 b$ limits the sample to firms that the DJSI subsequently dropped (we matched 139 cases, which we examine again in the deletion analysis), which ensures that we directly compare the benefits of addition to the costs of deletion; the paired subset has consistent results with the earlier analysis. Overall, the main effect of 
gaining status by being added to the DJSI is positive but, as expected, is less so for companies with better firm performance. We depict the extent of differences after discussing deletion models.

The deletion results in Models 6-8 support Hypothesis 2. Model 6 uses the aggregate measure of Current Firm Performance, finding support for H2 $(\beta=0.0066, \mathrm{p}<0.05)$. Model 7 uses the analyst recommendation as a measure of Expected Firm Performance, also finding a significant effect ( $\beta=0.0333$, $\mathrm{p}<0.05)$. Model 8a includes both measures of firm performance, finding consistent results $(\beta=0.0071$, $\mathrm{p}<0.05 ; \beta=0.0366 \mathrm{p}<0.05)$. Model $8 \mathrm{~b}$ focuses on the subsample of firms with both addition and deletion events (139 cases); the results are consistent with Model 8a. These results suggest that, as expected, firm performance counter-balances the loss of social status for investors.

Figure 1 depicts the results for additions. The figure uses coefficients from Model 4a of Table 2, based on calculations with the possible values of analyst recommendations ( 0 or 1$)$ and values of current firm performance one and two standard deviations above and below the mean. Interestingly, it shows that firms that are high on either measure of firm performance generate negative investor perceptions. As predicted, firms gain positive returns when they have lower levels of either current or expected firm performance. Firms with lowest performance on both dimensions gain the most from gaining status.

$* * * * * * * * *$ Figure 1 about here $* * * * * * * * * *$

Figure 2 reports parallel results for deletions, based on Model D3a of Appendix D (this model includes size, as did Model 4a for additions). Firms that are low on both measures of firm performance suffer most when they are dropped. The losses are less pronounced, though, as either current or expected firm performance increases. In general, the figures highlight the degree to which firm performance attenuates the impact of addition and deletion by the DJSI, that is, reduces the impact of the changes in social status on investor perceptions. Interestingly, in both cases expected firm performance carries more weight in generating investor perceptions than current firm performance, possibly because investors trust analyst in synthesizing available information and assessing future financial viability.

$* * * * * * * * *$ Figure 2 about here $* * * * * * * * * *$

The results for all measures of firm performance remain significant in sensitivity analyses 
(Appendix D). We added a control for slack resources based on the ratio of current liabilities to current assets (Models D1a and D2a); we did not include slack in other models because data availability significantly reduced the sample size. We added age, vertical and horizontal diversification, and R\&D and advertising expenditures: greater R\&D (Model D1b) has a negative impact with additions, while greater advertising expenditure (Model D2b) has a negative impact with deletions in fact substituting for the negative effect of deletion. Size (employees) has no significant impact when the analysis includes a constant (Model D3a), but exacerbates the negative impact of deletion when there is no constant (Model D3b: $\beta=-0.00134, p<0.05$ ); the negative impact of deletion is greatest for larger firms (similar to the negative effect of high advertising), just as larger firms benefit less from addition.

\section{Discussion and Conclusion}

This paper investigated how firm performance moderates the impact of changes in social status on investor perceptions. We developed theoretical arguments on why investors might follow the instrumental logic for evaluating status signals and base their perception of status changes on tangible indicators of firm performance. Our results show that gaining social status is less beneficial and losing social status is less detrimental for firms with better performance. Perhaps the most intriguing finding is that Wall Street views gaining and losing status with Main Street just as Main Street would (Lamin and Zaheer 2012) - in a positive and negative way respectively - but Wall Street changes this view once their evaluation incorporates information on firm performance.

We contribute to the organizational status, CSR, social evaluation and neo-institutional literatures. First, we answer a call in the status literature to evaluate the benefits and detriments to statusseeking and status-holding organizations (Chen et al, 2012: 304). We argue and find that benefits and detriments of status as measured by market reactions to the event of gaining and losing social status are moderated by firm performance. Thus, the greatest returns to gaining status and the greatest penalties for losing status accrue to the worst performers - an intriguing finding in itself. These phenomena - investor perceptions of firm value, moderated by firm performance - arise at the organizational level, distinct from the aspects of individual performance that have been the focus of most prior work on status. In turn, by 
studying status at the organizational level, we reinforce the emerging understanding of the different perspectives of Wall Street and Main Street (Lamin and Zaheer 2012).

Additionally, scholars are only starting to disentangle the causal effects of status, reputation, and quality on performance (Azoulay et al. 2014; Malter 2014; Simcoe and Waguespack 2011). This study focused on investor perceptions of status changes. The choice of empirical setting and method helped avoid the bias of several previous studies stemming from reputation and quality effects: while investors already have information about firm reputation and quality, they evaluate the new information about changes in status through the lens of firm performance.

Second, we extend the literatures on CSR and social evaluation. By drawing from the latter to understand how investor perceptions are formed in regards to CSR, we enhance our understanding of the mechanisms behind CSR value construction: consistent with market logic (Thornton et al. 2012), investors pay less attention to gaining social status when the firm has better performance, while punishing under-performers more when organizations lose social status. This result is important for both managers who seek to understand the consequences of their socially responsible and irresponsible activities, as well as for academics who study social irresponsibility and argue that perceptions of social irresponsibility are likely to generate strong observer reactions, often looming larger for the firm than perceptions of social responsibility (Lange and Washburn 2012; Muller and Kräussl 2011; Pfarrer et al. 2010).

Corporations face increasing social, political, and economic institutional pressures to undertake actions within the realm of CSR (Campbell 2007). Many firms view indices that list companies based on various dimensions of social and environmental performance as a valuable way of gaining social status (Schuler and Cording 2006). In addition, with increasing funds available in the market for socially responsible investment, managers commonly believe that joining such indices will generate financial benefits. While the literature on the relationship between corporate social performance (CSP) and corporate financial performance (CFP) often finds modest returns to CSR (Margolis and Elfenbein 2008), previous studies have not considered how the effect of CSR on firm value may vary with firm performance. Our results show that on average, firms that gain social status gain little in terms of 
abnormal returns (see Figure 1); however, firms that are performing worse gain from the recognition of their CSR activities and their status in this area. Moreover, despite Friedman's view of CSR (that the only responsibility of business is to shareholders), investors generally disapprove of losing social status (see Figure 2), likely due to potential consequences for business. This demonstrates the pervasiveness of CSR not only in the society but also in the markets (Cheng et al. 2013; Ioannou and Serafeim Forthcoming)

Third, we contribute to the neo-institutional literature by examining the role of private decentralized institutions (King et al. 2005). Akin to norms, codes of conduct, and industry standards, participation in the DJSI evaluation is voluntary, and diffuse actors rather than centralized brokers provide rewards and sanctions (Ingram and Silverman 2002). The work is one of the first to examine the DJSI, using a robust methodology and triangulating the event study analysis with qualitative data from interviews and archival search, previously called for (Margolis and Walsh 2003). We show that while sanctions (i.e., deletion) from the DJSI generally have impact (i.e., the market punishes all deleted firms), by contrast rewards (i.e., addition) only apply to firms that perform below the mean of performance.

Furthermore, in addition to the empirical contributions we noted above, the paper examines the data-generating process by seeking the opinions of the parties most interested in the links between social and financial performance, including corporations, analysts, and investors. By examining how the market values social status signals, we address a gap in our understanding of perceptions of CSR by key stakeholders in capital markets. Interestingly, the effect of analyst recommendations on investor perceptions is greater than that of current firm performance; this is possibly showing how much investors trust analysts in synthesizing available information and assessing future financial viability.

This research also has practical implications. Social indices are not only a meaningful source of social status but also important investment tools. Currently, about $11 \%$ of the $\$ 25$ trillion in total assets under professional management in the United States involves socially responsible investing (SIF 2007), whereby investors seek to attain both financial returns and social good. Globally, this number is even higher; the 534 institutional investors in the Carbon Disclosure Project represent more than $\$ 64$ trillion of assets (PWC 2010) while the 784 signatories to the UN Principles for Responsible Investment hold \$22 
trillion of assets under management (PRI 2010). Evaluating the impact of additions and deletions at the DJSI is important to both market and non-market actors seeking to understand the role of social indices. Furthermore, our discussion of conditions under which the benefits or detriments to gaining or losing status are lower provides the basis for active management of social status.

The study has limitations that provide direction to future research. First, future studies could examine more firms, including those for which CRSP or Capital IQ lack data. Second, further work could examine other elements of social status beyond social indices, as well as firm performance beyond analyst recommendations and profitability. Third, research could examine other mechanisms for market interpretation of social status signals. Finally, the dynamism of organizational status, particularly with different stakeholders, warrants further attention: e.g., future research could study periods that experience major shocks to social status and firm performance, such as the financial recession and the Gulf Oil spill.

Other questions also merit attention. Figure 1 suggests that high performing firms, particularly those with high expected performance, pay a penalty when they gain status by being added to the DJSI. It would be useful to investigate the source of this apparent penalty, which might arise because investors fear that high performing firms will take attention away from core activities as they attend to social goals. In turn, the difference in the impact of expected and current firm performance merits further attention; organizational studies on the role of analysts mainly focus on their effect on firms and CEOs, while we show analysts significantly affect investor perceptions of firm value (more so than firm performance). Most generally, this research advances our understanding of CSR and organizational status. The core finding that firm performance moderates the impact of changes in social status on investor perceptions is robust and important. We hope the work will open lines of inquiry that will broaden our understanding of this phenomenon. 


\section{References}

Ashforth, B.E., B.W. Gibbs. 1990. The Double-Edge of Organizational Legitimation. Organization Science 1(2) 177-194.

Azoulay, P., T. Stuart, Y. Wang. 2014. Matthew: Effect or Fable? Management Science 60(1) 92-109.

Baron, D.P. 1995. Integrated Strategy: Market and Nonmarket Components. California Management Review 37(2) 47.

Bebchuk, L.A., A. Cohen, C.C. Wang. 2013. Learning and the Disappearing Association Between Governance and Returns. Journal of Financial Economics 108(2) 323-348.

Bendersky, C., N.P. Shah. 2012. The Cost of Status Enhancement: Performance Effects of Individuals' Status Mobility in Task Groups. Organization Science 23(2) 308-322.

Benjamin, B.A., J.M. Podolny. 1999. Status, Quality, and Social Order in the California Wine Industry. Administrative Science Quarterly 44(3) 563-589.

Bitektine, A. 2011. Toward a Theory of Social Judgments of Organizations: The Case of Legitimacy, Reputation, and Status. The Academy of Management Review (AMR) 36(1) 151-179.

Bonardi, J.-P., A.J. Hillman, G.D. Keim. 2005. The Attractiveness of Political Markets: Implications for Firm Strategy. The Academy of Management Review 30(2) 397-413.

Bothner, M.S., Y.-K. Kim, E.B. Smith. 2012. How Does Status Affect Performance? Status as an Asset vs. Status as a Liability in the PGA and NASCAR. Organization Science 23(2) 416-433.

Campbell, J.L. 2007. Why Would Corporations Behave in Socially Responsible Ways? An Institutional Theory of Corporate Social Responsibility Academy of Management Review 32(3) 946-967.

Campbell, J.Y., A.W. Lo, A.C. MacKinlay. 2007. The Econometrics of Financial Markets. PRINCETON UNIVERSITY PRESS.

Chatterji, A.K., D.I. Levine, M.W. Toffel. 2009. How Well Do Social Ratings Actually Measure Corporate Social Responsibility? Journal of Economics \& Management Strategy 18(1) 125-169.

Chen, Y.-R., R.S. Peterson, D.J. Phillips, J.M. Podolny, C.L. Ridgeway. 2012. Introduction to the Special Issue: Bringing Status to the Table-Attaining, Maintaining, and Experiencing Status in Organizations and Markets. Organization Science 23(2) 299-307.

Cheng, B., I. Ioannou, G. Serafeim. 2013. Corporate social responsibility and access to finance. Strategic Management Journal 35(1) 1-23.

Cheung, A.W.K. 2011. Do Stock Investors Value Corporate Sustainability? Evidence from an Event Study. J Bus Ethics 99(2) 145-165.

Cho, C.H., D.M. Patten. 2007. The role of environmental disclosures as tools of legitimacy: A research note. Accounting, Organizations and Society 32(7-8) 639-647.

Cohen, B.D., T.J. Dean. 2005. Information Asymmetry and Investor Valuation of IPOs: Top Management Team Legitimacy as a Capital Market Signal Strategic Management Journal 26(7) 683-690.

Consolandi, C., A. Jaiswal-Dale, E. Poggiani, A. Vercelli. 2009. Global Standards and Ethical Stock Indexes: The Case of the Dow Jones Sustainability Stoxx Index. J Bus Ethics 87(0) 185-197.

Delmas, M.A., M.W. Toffel. 2008. Organizational responses to environmental demands: opening the black box. Strategic Management Journal 29(10) 1027-1055.

Doh, J.P., S.D. Howton, S.W. Howton, D.S. Siegel. 2010. Does the Market Respond to an Endorsement of Social Responsibility? The Role of Institutions, Information, and Legitimacy. Journal of Management 36(6) 1461-1485.

Espeland, W.N., M. Sauder. 2007. Rankings and Reactivity: How Public Measures Recreate Social Worlds. American Journal of Sociology 113(1) 1-40.

Fowler, S.J., C. Hope. 2007. A critical review of sustainable business indices and their impact. J Bus Ethics 76(3) 243-252.

Freeman, R.E. 1984. Strategic management: A stakeholder approach. Pitman, Boston.

Friedman, M. 1970. The Social responsibility of Business if to increase its profits New York Time Magazine. The New York Times Company, New York.

Gardberg, N.A., C.J. Fombrun. 2006. Corporate Citizenship: Creating Intangible Assets Across Institutional Environments Academy of Management Review 31(2) 329-346. 
Godfrey, P.C. 2005. The relationship Between Corporate Philanthropy and Shareholder Wealth: A Risk Management Perspective Academy of Management Review 30(4) 777-798.

Godfrey, P.C., C.B. Merrill, J.M. Hansen. 2009. The relationship between corporate social responsibility and shareholder value: an empirical test of the risk management hypothesis. Strategic Management Journal 30(4) 425-445.

Graffin, S.D., J.B. Wade, J.F. Porac, R.C. McNamee. 2008. The Impact of CEO Status Diffusion on the Economic Outcomes of Other Senior Managers. Organization Science 19(3) 457-474.

Hirsch, F. 1977. Social Limits to Growth. Routledge \& Kegan Pual., London, U.K.

Hirsch, P.M. 1975. Organizational Effectiveness and the Institutional Environment. Administrative Science Quarterly 20(3) 327-344.

Hybels, R.C. 1995. On legitimacy, legitimation, and organizations: A critical review and integrative theoretical model. Academy of Management Journal(00014273) 241-241.

Ingram, P., B.S. Silverman. 2002. The new institutionalism in strategic management. P. Ingram, B.S. Silverman, eds. Advances in strategic management. JAI Press, Greenwich, CT, 1-32.

Ioannou, I., G. Serafeim. Forthcoming. The Impact of Corporate Social Responsibility on Investment Recommendations: Analysts' Perceptions and Shifting Institutional Logics. Strategic Management Journal.

King, A.A., M.J. Lenox, A. Terlaak. 2005. The Strategic Use of Decentralized Institutions: Exploring Certification with the ISO 14001 Management Standard. Academy of Management Journal 48(6) 1091-1106.

Kostova, T., S. Zaheer. 1999. Organizational Legitimacy Under Conditions of Complexity: The Case of the Multinational Enterprise. The Academy of Management Review 24(1) 64-81.

Lackmann, J., J. Ernstberger, M. Stich. 2012. Market Reactions to Increased Reliability of Sustainability Information. J Bus Ethics 107(2) 111-128.

Lamin, A., S. Zaheer. 2012. Wall Street vs. Main Street: Firm Strategies for Defending Legitimacy and Their Impact on Different Stakeholders. Organization Science 23(1) 47-66.

Lange, D., N.T. Washburn. 2012. Understanding Attributions of Corporate Social Irresponsibility Academy of Management Review 37(2) 300-326.

López, M.V., A. Garcia, L. Rodriguez. 2007. Sustainable Development and Corporate Performance: A Study Based on the Dow Jones Sustainability Index. J Bus Ethics 75(3) 285-300.

Love, E., M. Kraatz. 2009. Character, Conformity, or the Bottom Line? How and Why Downsizing Affected Corporate Reputation. The Academy of Management Journal (AMJ) 52(2) 314-335.

Malter, D. 2014. On the causality and cause of returns to organizational status: Evidence from the grands crus classés of the Médoc. Administrative Science Quarterly.

Margolis, J.D., H.A. Elfenbein. 2008. Do Well by Doing Good? Don't Count on It. Harvard Business Review 86(1) 19-20.

Margolis, J.D., H.A. Elfenbein, J.P. Walsh. 2007. Does It Pay To Be Good? A Meta-Analysis and Redirection of Research on the Relationship Between Corporate Social and Financial Performance. Under Review.

Margolis, J.D., J.P. Walsh. 2003. Misery Loves Companies: Rethinking Social Initiatives by Business. Administrative Science Quarterly 48(2) 268-305.

McWilliams, A., D. Siegel. 1997. Event Studies in Management Research: Theoretical and Empirical Issues. The Academy of Management Journal 40(3) 626-657.

McWilliams, A., D. Siegel. 2000. Corporate Social Responsibility and Financial Performance: Correlation or Misspecification? Strategic Management Journal 21(5) 603-609.

McWilliams, A., D. Siegel. 2001. Corporate Social Responsibility: A Theory of the Firm Perspective. The Academy of Management Review 26(1) 117-127.

Meyer, J.W., B. Rowan. 1977. Institutionalized Organizations: Formal Structure as Myth and Ceremony. The American Journal of Sociology 83(2) 340-363.

Michlik, P., A.R. Rubash. 2011. Corporate value changes arising from demonstrated sustainability. International Journal of Sustainable Strategic Management 2(1) 13-32. 
Muller, A., R. Kräussl. 2011. Doing good deeds in times of need: a strategic perspective on corporate disaster donations. Strategic Management Journal 32(9) 911-929.

Neeley, T.B. 2013. Language Matters: Status Loss and Achieved Status Distinctions in Global Organizations. Organization Science 24(2) 476-497.

Orlitzky, M. 2013. Corporate Social Responsibility, Noise, and Stock Market Volatility. The Academy of Management Perspectives 27(3) 238-254.

Orlitzky, M., F.L. Schmidt, S.L. Rynes. 2003. Corporate Social and Financial Performance: A MetaAnalysis. Organization Studies 24(3) 403-441.

Parker, D., K. Hartley. 1991. Do changes in organizational status affect financial performance? Strategic Management Journal 12(8) 631-641.

Pfarrer, M.D., T.G. Pollock, V.P. Rindova. 2010. A Tale of Two Assets: The Effects of Firm Reputation and Celebrity on Earnings Surprises and Investors' Reactions. Academy of Management Journal 53(5) 1131-1152.

Pfeffer, J. 1981. Power in organizations. Pitman Pub. , Marshfield, MA.

Phillips, D.J., E.W. Zuckerman. 2001. Middle-Status Conformity: Theoretical Restatement and Empirical Demonstration in Two Markets. American Journal of Sociology 107(2) 379-429.

Podolny, J.M. 1993. A status-based model of market competition. American Journal of Sociology 829872.

Podolny, J.M. 2005. Status Signals. Princeton University Press, Princeton, NJ.

Pontikes, E.G. 2012. Two Sides of the Same Coin: How Ambiguous Classification Affects Multiple Audiences' Evaluations. Administrative Science Quarterly 57(1) 81-118.

Porter, M.E., M.R. Kramer. 2006. Strategy \& Society: The Link Between Competitive Advantage and Corporate Social Responsibility. Harvard Business Review 84(12) 78-92.

PRI. 2010. Annual Report of the PRI Initiative.

PWC. 2010. Carbon Disclosure Project 2010: Global 500 Report PriceWaterhouseCoopers, ed.

Robinson, M., A. Kleffner, S. Bertels. 2011. Signaling Sustainability Leadership: Empirical Evidence of the Value of DJSI Membership. J Bus Ethics 101(3) 493-505.

Ruef, M., W.R. Scott. 1998. A Multidimensional Model of Organizational Legitimacy: Hospital Survival in Changing Institutional Environments. Administrative Science Quarterly 43(4) 877-904.

Sauder, M., W.N. Espeland. 2009. The Discipline of Rankings: Tight Coupling and Organizational Change. American Sociological Review 74 63-82.

Schuler, D.A., M. Cording. 2006. A Corporate Social Performance-Corporate Financial Performance Behavioral Model for Consumers Academy of Management Review 31(3) 540-558.

Shapiro, C. 1982. Consumer Information, Product Quality, and Seller Reputation. The Bell Journal of Economics 13(1) 20-35.

Shrivastava, P. 1987. Bhopal: Anatomy of a Crisis. Ballinger, Cambridge, MA.

SIF. 2007. Report on Responsible Investing Trends in the U.S. Biennial Reports: Socially Responsible Investing Trends, Washington DC.

Simcoe, T.S., D.M. Waguespack. 2011. Status, Quality, and Attention: What's in a (Missing) Name? Management Science 57(2) 274-290.

Singh, J.V., D.J. Tucker, R.J. House. 1986. Organizational Legitimacy and the Liability of Newness. Administrative Science Quarterly 31(2) 171-193.

Spence, M. 1973. Job Market Signaling. The Quarterly Journal of Economics 87(3) 355-374.

Stigler, G.J. 1961. The Economics of Information. The Journal of Political Economy 69(3) 213-225.

SustainAbility. 2012. Rate the Raters: Polling the Experts.

Terlaak, A., A.A. King. 2006. The effect of certification with the ISO 9000 Quality Management Standard: A signaling approach. Journal of Economic Behavior \& Organization 60(4) 579-602.

Thornton, P.H., W. Ocasio, M. Lounsbury. 2012. The institutional logics perspective: a new approach to culture, structure, and process. Oxford University Press, Oxford. 
UNEPFI. 2008. If you ask us...Understanding Corporate Sustainability Disclosure Requests. A research paper by the Noth American Task Force UNEP Finance Initiative Presented at the World Economic Forum in Davos.

Waddock, S. 2008. Building a New Institutional Infrastructure for Corporate Responsibility. Academy of Management Perspectives 22(3) 87-108.

Washington, M., E.J. Zajac. 2005. Status Evolution and Competition: Theory and Evidence. The Academy of Management Journal 48(2) 282-296.

Weaver, G.R., L.K. Trevino, P.L. Cochran. 1999. Integrated and Decoupled Corporate Social Performance: Management Commitments, External Pressures, and Corporate Ethics Practices. The Academy of Management Journal 42(5) 539-552.

Werdigier, J. 2011, February 1. BP to Pay First Dividend Since Gulf of Mexico Spill The New York Times.

Westphal, J.D., M.B. Clement. 2008. Sociopolitical Dynamics in Relations Between Top Managers and Security Analysts: Favor Rendering, Reciprocity, and Analyst Stock Recommendations Academy of Management Journal 51(5) 873-897.

Westphal, J.D., E.J. Zajac. 1998. The Symbolic Management of Stockholders: Corporate Governance Reforms and Shareholder Reactions. Administrative Science Quarterly 43(1) 127-153.

White, H.C. 2001. Markets from networks: Socioeconomic models of production. Princeton University Press, Princeton, NJ.

Wood, D.J. 1991. Corporate Social Performance Revisited. Academy of Management Review 16(4) 691718.

Zhang, J., X.R. Luo. 2013. Dared to Care: Organizational Vulnerability, Institutional Logics, and MNCs' Social Responsiveness in Emerging Markets. Organization Science.

Zhao, W., X. Zhou. 2011. Status Inconsistency and Product Valuation in the California Wine Market. Organization Science 22(6) 1435-1448.

Ziegler, A., M. Schroder. 2010. What determines the inclusion in a sustainability stock index? A panel data analysis for european firms. Ecological Economics 69(4) 848-856.

Zuckerman, E.W. 1999. The Categorical Imperative: Securities Analysts and the Illegitimacy Discount. The American Journal of Sociology 104(5) 1398-1438. 
Figure 1. Impact of Firm Performance on Investor Perceptions of Gaining Status

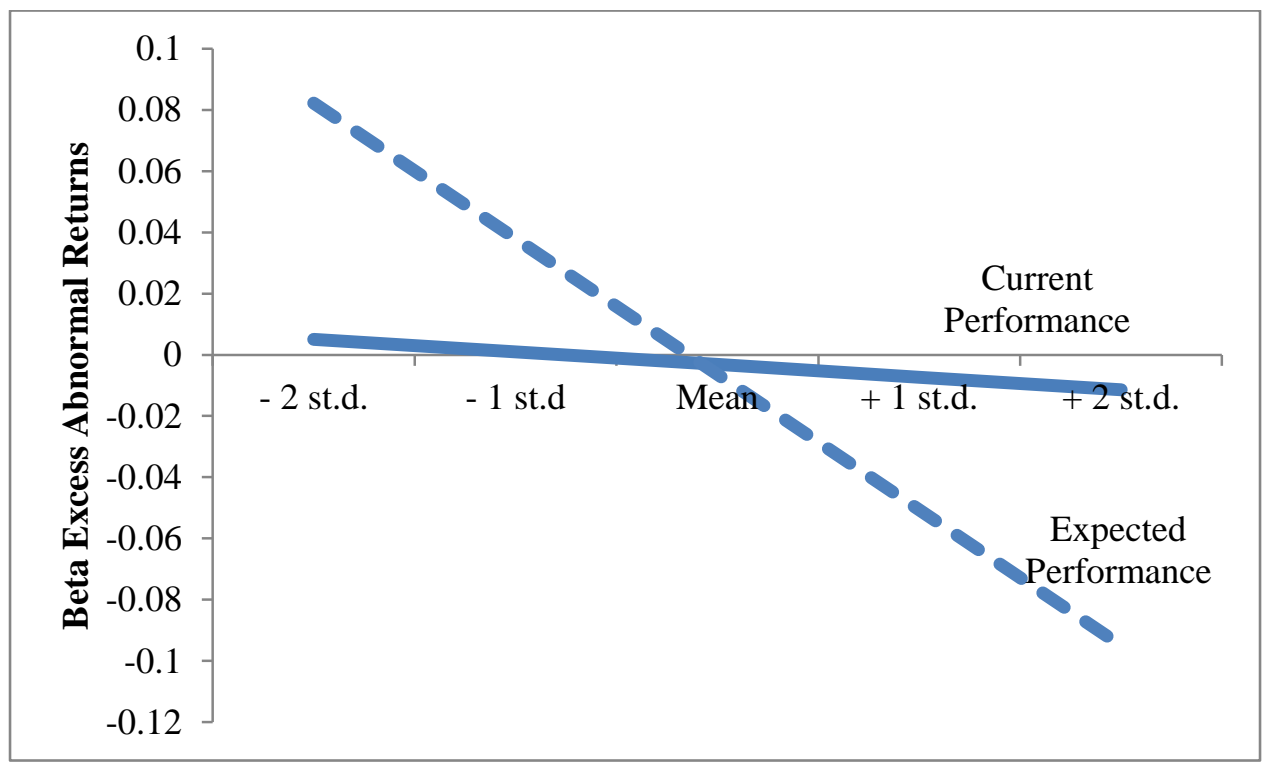

Notes: This graph is plotted based on the parameter estimates in Model 4a of Table 2. We use the mean value for other interval variables and the reference category for other categorical variables.

Figure 2. Impact of Firm Performance on Investor Perceptions of Losing Status

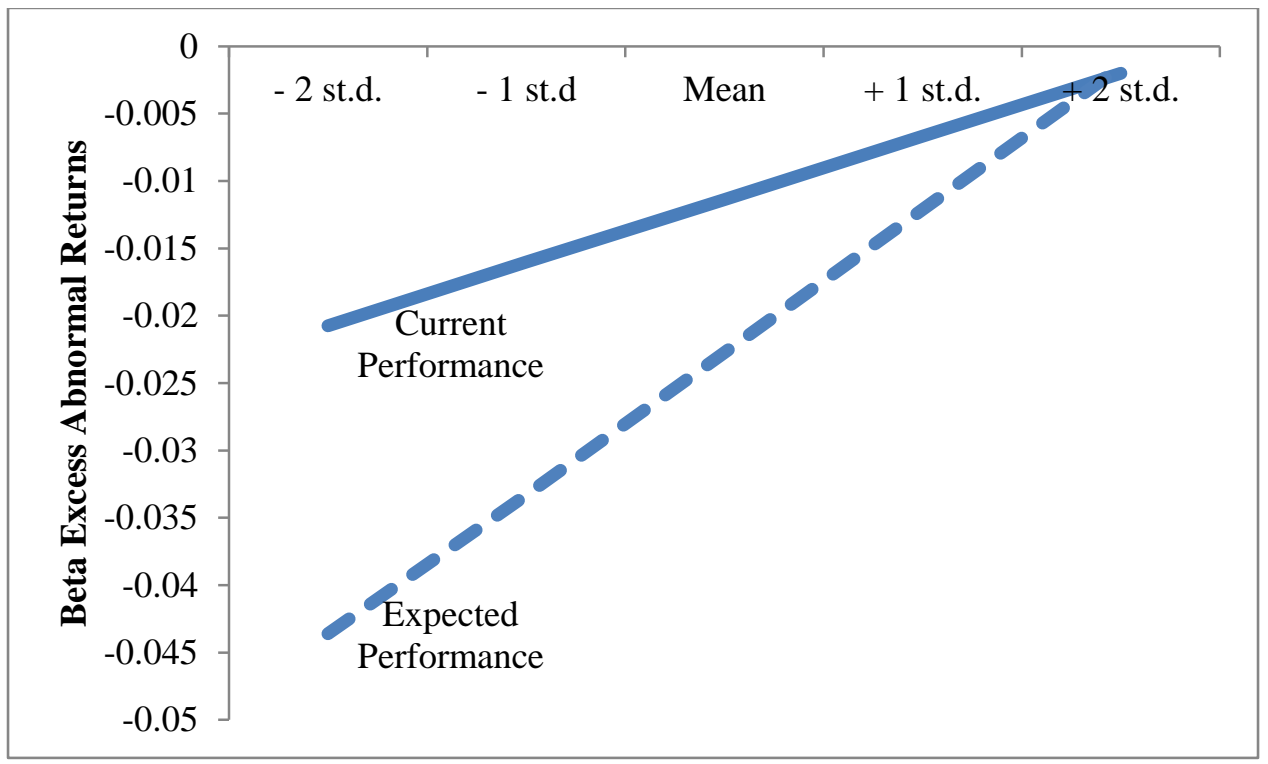

Notes: This graph is plotted based on the parameter estimates in Model D3a of Appendix D. We use the mean value for other interval variables and the reference category for other categorical variables. 
Table 1a. Descriptive Statistics: Standardized Values of Items of Current Firm Performance

\begin{tabular}{lccccccc}
\hline & $(1)$ & $(2)$ & $(3)$ & $(4)$ & $(5)$ & $(6)$ & $(7)$ \\
\hline 1. Current Firm Performance & 1.00 & & & & & & \\
2. EBIT margin & 0.75 & 1.00 & & & & & \\
3. ECO margin & 0.79 & 0.60 & 1.00 & & & & \\
4. Net Income margin & 0.70 & 0.38 & 0.90 & 1.00 & & & \\
5. ROA & 0.72 & 0.60 & 0.23 & 0.17 & 1.00 & & \\
6. ROE & 0.56 & 0.21 & 0.26 & 0.22 & 0.31 & 1.00 & \\
7. ROC & 0.78 & 0.50 & 0.34 & 0.25 & 0.94 & 0.38 & 1.00 \\
\hline Mean & 0.01 & 0 & 0 & 0 & 0 & 0 & 0 \\
S.D. & 0.71 & 1 & 1 & 1 & 1 & 1 & 1 \\
Min & -4.16 & -5.23 & -8.71 & -13.46 & -3.16 & -5.73 & -2.79 \\
Max & 2.67 & 4.17 & 4.5 & 3.18 & 5.43 & 13.97 & 6.42 \\
N & 418 & 379 & 417 & 417 & 413 & 412 & 375 \\
\hline
\end{tabular}

Table 1b. Descriptive Statistics: Dependent and Independent Variables

\begin{tabular}{|c|c|c|c|c|c|c|c|c|c|c|c|c|c|c|c|c|}
\hline & $(1)$ & $(2)$ & (3) & $(4)$ & $(5)$ & $(6)$ & $(7)$ & $(8)$ & $(9)$ & $(10)$ & $(11)$ & $(12)$ & $(13)$ & $(14)$ & $(15)$ & $(16)$ \\
\hline 1. Abnormal returns following the addition & 1.00 & & & & & & & & & & & & & & & \\
\hline 2. Abnormal returns following the deletion & -0.21 & 1.00 & & & & & & & & & & & & & & \\
\hline 3. Expected Firm Performance & -0.16 & 0.13 & 1.00 & & & & & & & & & & & & & \\
\hline 4. Current Firm Performance & -0.12 & 0.16 & 0.02 & 1.00 & & & & & & & & & & & & \\
\hline 5. Size (log of the number of employees) & -0.18 & -0.12 & 0.07 & -0.09 & 1.00 & & & & & & & & & & & \\
\hline 6. Sector: Basic resources & -0.02 & 0.22 & -0.12 & -0.06 & -0.02 & 1.00 & & & & & & & & & & \\
\hline 7. Sector: Consumer & -0.11 & -0.01 & 0.19 & 0.04 & -0.16 & -0.30 & 1.00 & & & & & & & & & \\
\hline 8. Sector: Industrial & 0.00 & -0.10 & 0.02 & -0.02 & 0.02 & -0.16 & -0.32 & 1.00 & & & & & & & & \\
\hline 9. Sector: Services & 0.12 & -0.06 & -0.13 & 0.02 & 0.16 & -0.28 & -0.57 & -0.30 & 1.00 & & & & & & & \\
\hline 11. Geography: North America & 0.08 & 0.08 & -0.15 & 0.08 & 0.05 & -0.06 & 0.10 & -0.03 & -0.03 & -0.83 & 1.00 & & & & & \\
\hline 12. Geography: Other & -0.12 & 0.02 & 0.04 & -0.05 & -0.02 & 0.10 & -0.06 & 0.09 & -0.08 & -0.17 & -0.41 & 1.00 & & & & \\
\hline 13. Negative news 14 months before announcement & -0.03 & -0.06 & 0.22 & -0.05 & -0.01 & 0.11 & -0.11 & 0.02 & 0.02 & 0.11 & -0.08 & -0.05 & 1.00 & & & \\
\hline 14. Positive news 14 months before announcement & -0.01 & 0.11 & 0.22 & -0.02 & -0.04 & 0.08 & 0.04 & 0.00 & -0.10 & 0.06 & -0.10 & 0.08 & 0.27 & 1.00 & & \\
\hline 15. Negative news 1 week before announcement & -0.07 & -0.35 & 0.10 & -0.02 & -0.14 & -0.05 & 0.08 & 0.02 & -0.06 & 0.02 & -0.02 & -0.01 & 0.17 & 0.00 & 1.00 & \\
\hline 16. Positive news 1 week before announcement & 0.01 & 0.02 & 0.14 & 0.00 & 0.00 & 0.05 & -0.02 & -0.05 & 0.03 & 0.06 & -0.03 & -0.04 & 0.11 & 0.02 & -0.02 & 1.00 \\
\hline Mean & -0.002 & -0.004 & 0.02 & 0.01 & 10.42 & 0.13 & 0.38 & 0.14 & 0.35 & 0.26 & 0.67 & 0.08 & 1.5 & 0.31 & 0.11 & 0.09 \\
\hline S.D. & 0.027 & 0.03 & 0.15 & 0.71 & 1.35 & 0.34 & 0.49 & 0.35 & 0.48 & 0.44 & 0.47 & 0.27 & 3.2 & 1.1 & 0.74 & 0.46 \\
\hline Min & -0.109 & -0.11 & 0 & -4.16 & 6.55 & 0 & 0 & 0 & 0 & 0 & 0 & 0 & 0 & 0 & 0 & 0 \\
\hline $\mathrm{N}$ & 269 & 150 & 418 & 418 & 418 & 418 & 418 & 418 & 418 & 418 & 418 & 418 & 418 & 418 & 418 & 418 \\
\hline
\end{tabular}


Table 2. OLS Estimates of the Impact of Addition and Deletion from the DJSI on Firms' Abnormal Stock Returns (Beta Excess Returns)

\begin{tabular}{|c|c|c|c|c|c|c|c|c|c|c|}
\hline & \multicolumn{5}{|c|}{ H1: Addition to DJSI (Gain of Status) } & \multicolumn{5}{|c|}{ H2: Deletion from DJSI (Loss of Status) } \\
\hline & 1 & 2 & 3 & $4 a$ & 4b. Paired & 5 & 6 & 7 & $8 \mathbf{a}$ & 8b. Paired \\
\hline Current Firm & & $-0.0061 * * *$ & & $-0.0058 * *$ & $-0.0318 * * *$ & & $0.0066^{* *}$ & & $0.0071 * *$ & $0.0347 * *$ \\
\hline Performance (\#) & & $(0.0023)$ & & $(0.0023)$ & $(0.0116)$ & & $(0.0035)$ & & $(0.0035)$ & $(0.0207)$ \\
\hline Expected Firm & & & $-0.0279 * * *$ & $-0.0268 * * *$ & $-0.0084 * *$ & & & $\mathbf{0 . 0 3 3 3} * *$ & $0.0366^{* *}$ & $0.0057 *$ \\
\hline Performance (\#) & & & $(0.0097)$ & $(0.0097)$ & $(0.0033)$ & & & $(0.0205)$ & $(0.0203)$ & $(0.0039)$ \\
\hline Size (log of & $-0.0034 * *$ & $-0.0034 * *$ & $-0.0031^{* *}$ & $-0.0031 * *$ & $-0.0047 * *$ & & & & & \\
\hline employees) & $(0.0014)$ & $(0.0013)$ & $(0.0013)$ & $(0.0013)$ & $(0.0018)$ & & & & & \\
\hline Sector: Basic & -0.0057 & -0.0060 & -0.0066 & -0.0073 & -0.0108 & $0.0194 * *$ & $0.0221 * * *$ & $0.0193 * *$ & $0.0223 * * *$ & $0.0240 * *$ \\
\hline Resource (v. Svc) & $(0.0054)$ & $(0.0053)$ & $(0.0053)$ & $(0.0053)$ & $(0.0087)$ & $(0.008)$ & $(0.0081)$ & $(0.0080)$ & $(0.0081)$ & $(0.0094)$ \\
\hline Sector: Consumer & $-0.0069 *$ & $-0.0083^{* *}$ & $-0.0076^{*}$ & $-0.0089 * *$ & $-0.0095^{*}$ & 0.004 & 0.0067 & 0.0028 & 0.0055 & 0.0051 \\
\hline (v. Services) & $(0.0040)$ & $(0.004)$ & $(0.004)$ & (0.004) & $(0.0056)$ & $(0.0057)$ & $(0.0058)$ & $(0.0057)$ & $(0.0058)$ & $(0.0061)$ \\
\hline Sector: Industrial & -0.0019 & -0.0023 & -0.0023 & -0.0027 & -0.0056 & -0.003 & -0.0017 & -0.003 & -0.0015 & -0.0043 \\
\hline (v. Services) & $(0.0055)$ & $(0.0055)$ & $(0.0054)$ & $(0.0054)$ & $(0.0071)$ & $(0.007)$ & $(0.0069)$ & (0.0069) & $(0.0069)$ & $(0.0075)$ \\
\hline North America & 0.0017 & 0.0028 & 0.003 & 0.004 & $0.0201 * * *$ & 0.005 & 0.0050 & 0.0060 & 0.0061 & 0.0042 \\
\hline (v. EU) & $(0.0038)$ & $(0.0038)$ & $(0.0038)$ & $(0.0038)$ & $(0.0062)$ & $(0.0059)$ & $(0.0058)$ & $(0.0059)$ & $(0.0058)$ & $(0.0064)$ \\
\hline Other Countries & -0.0112 & -0.0111 & -0.0111 & -0.0110 & -0.0063 & 0.0022 & 0.0016 & 0.0033 & 0.0028 & -0.0016 \\
\hline (v. EU) & $(0.0069)$ & $(0.0069)$ & $(0.0068)$ & $(0.0068)$ & $(0.0106)$ & $(0.0102)$ & $(0.0102)$ & $(0.0102)$ & $(0.0101)$ & $(0.0111)$ \\
\hline Negative press: & -0.0002 & -0.0002 & -0.0003 & -0.0003 & -0.0007 & -0.0001 & -0.0002 & -0.0002 & -0.0002 & -0.0004 \\
\hline Past 14 months & $(0.0006)$ & $(0.0006)$ & $(0.0006)$ & $(0.0006)$ & (0.0009) & $(0.0007)$ & $(0.0007)$ & $(0.0007)$ & $(0.0007)$ & $(0.0007)$ \\
\hline Positive press: & 0.0012 & 0.0015 & 0.0012 & 0.0015 & 0.0023 & 0.003 & 0.0039 & 0.0029 & 0.0039 & 0.0035 \\
\hline Past 14 months & $(0.002)$ & $(0.002)$ & $(0.002)$ & $(0.002)$ & $(0.0027)$ & $(0.0026)$ & $(0.0027)$ & $(0.0026)$ & $(0.0026)$ & $(0.0027)$ \\
\hline Negative press: & -0.0025 & -0.0031 & -0.0027 & -0.0033 & -0.0024 & $-0.0092 * * *$ & $-0.0083 * * *$ & $-0.009 * * *$ & $-0.008 * * *$ & $-0.0075^{* * *}$ \\
\hline 1 week before & $(0.0041)$ & $(0.0041)$ & $(0.0040)$ & $(0.004)$ & $(0.0043)$ & $(0.0022)$ & $(0.0022)$ & $(0.0022)$ & $(0.0022)$ & $(0.0025)$ \\
\hline Positive press: & 0.0043 & 0.0047 & 0.0050 & 0.0055 & -0.0009 & -0.0003 & -0.0002 & -0.0002 & $-9.44 \mathrm{e}-05$ & -0.0002 \\
\hline 1 week before & $(0.006)$ & $(0.0061)$ & $(0.006)$ & $(0.006)$ & $(0.0096)$ & $(0.004)$ & $(0.0036)$ & $(0.0036)$ & $(0.0035)$ & $(0.0036)$ \\
\hline \multirow[t]{2}{*}{ Constant } & $0.0367 * *$ & $0.0366^{* * *}$ & $0.0345 * *$ & $0.0344 * *$ & $0.0380^{*}$ & $-0.0103 *$ & $-0.0119 *$ & $-0.0110 *$ & $-0.0129 * *$ & $-0.0099 *$ \\
\hline & $(0.0144)$ & $(0.0143)$ & $(0.0142)$ & $(0.0141)$ & (0.0199) & $(0.0063)$ & $(0.0063)$ & $(0.0063)$ & $(0.0063)$ & $(0.0069)$ \\
\hline Observations & 268 & 267 & 268 & 267 & 139 & 150 & 150 & 150 & 150 & 139 \\
\hline R-squared & 0.063 & 0.087 & 0.092 & 0.114 & 0.252 & 0.180 & 0.201 & 0.195 & 0.219 & 0.191 \\
\hline
\end{tabular}

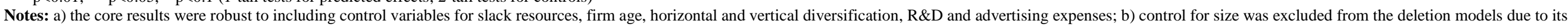
insignificance (see Appendix D); c) the "Paired" subsample (Models $4 \mathrm{~b}$ and $8 \mathrm{~b}$ ) included only firms that were added and subsequently dropped by the DJSI.

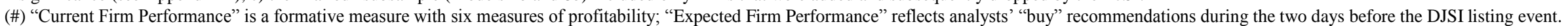




\section{APPENDIX A. Evaluation of DJSI}

DJSI in Media and Academia. We began our study by calculating several measures that reflect the evolution of the attention that CSR, including its sustainability subcomponent, has received in the social institutional environment in which market and non-market actors operate. Following methodology from Bebchuk, Cohen, and Wang (2013), we examined attention both in the media and academic research. Media references and coverage of CSR are relevant for two reasons: (1) greater attention by journalists may be a mechanism for information diffusion, influencing market and non-market actors and leading them to pay more attention to such issues; and (2) journalists talk with and write for market and nonmarket actors, so greater coverage of CSR may be a mechanism for generating greater interest in these issues. Academic research is relevant to market and non-market actors because it offers ideas and results that can affect their choices and which issues they pay attention to.

We obtained quantitative measures for the media and academic interest in CSR through searches in Lexis-Nexis and Business Source Complete. Figure 3A plots normalized percentage increase of the media and academic interest in each calendar year from 1998 to 2009, with 1998 being the base year for comparison. This figure plots two time series: (1) the percentage increase of unique newspaper articles, wires, and publications in major world publications with words "sustainability" and "Corporate Social Responsibility"; (2) the percentage increase of academic journal articles with these terms in the abstract of author-supplied keywords (all normalized by their 1998 values). We searched for these two terms because sustainability and CSR are often used interchangeably. All series demonstrate a gradual increase in the attention to sustainability and CSR during the decade. This trend exhibits growing institutional pressure and the potential for social status, provided by the social indices.

We then examined the attention that media and academics have paid to the DJSI itself. Figure 3B exhibits the same time series of the percentage increase in the number of unique newspaper articles, wires, and publications in major world news outlets that reference the Dow Jones Sustainability Index, and the percentage increase of academic journal articles that reference the index in the abstract of author-supplied keywords, normalized by the 1998 value of zero articles (since the index was founded in 1999). We found a significant escalation in media attention to the DJSI but virtually absent academic interest. This difference points to a persistent gap between practitioners and academics; nonetheless, because academic papers are often published with a significant time lag after research occurs, it is possible that there will be future overlapping interest in DJSI among the media and academia. 


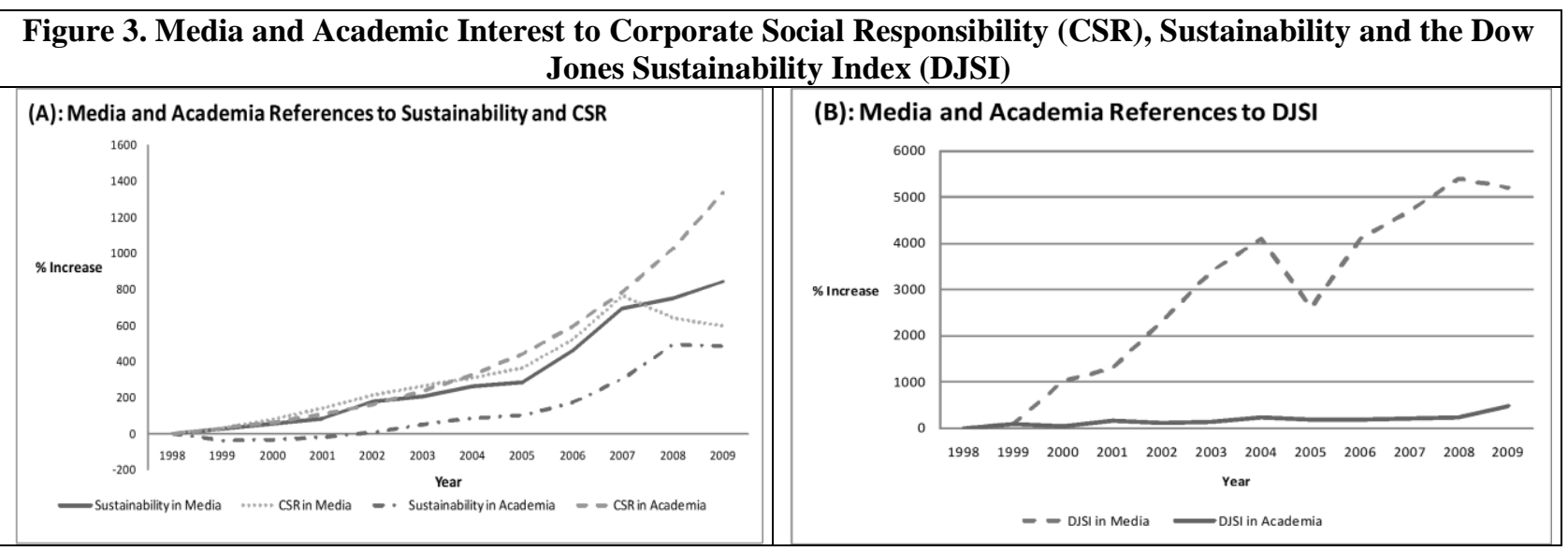

DJSI and Social Status. Social indices reflect two processes. First, they define standards for socially responsible practices. ${ }^{2}$ Second, they provide a system through which organizations can communicate the best use of these standard practices. Thus, they both help set the rules of the game by identifying the criteria and confer status on companies that best fit these rules by ceremonially adding them to the DJSI. While most previous studies have focused on the reasons why firms seek to engage in CSR and what effect it has on firm performance (Campbell 2007; Godfrey 2005; Godfrey et al. 2009; McWilliams and Siegel 2001), few have separated out the mechanisms of why and when CSR matters (Margolis et al. 2007; Orlitzky et al. 2003). We follow the argument that CSR can create intangible assets that help firms by establishing legitimacy and competitive advantage (Gardberg and Fombrun 2006). We also reflect the information literature argument that social status denotes the persistence of quality and, due to economies of information search, commands a higher price (Stigler 1961). Hence, we argue that the status effects of the addition to the index will result in economic value.

While being listed on a social index reflects the adoption of socially responsible practices, the opposite logic does not apply. Firms that a socially responsible index does not add to its list may still adopt some or even all of the practices. CSR engagement in practice is an internal organizational act that can go unrecognized; even if firms attempt to release the information, stakeholders may not trust the

\footnotetext{
${ }^{2}$ DJSI assessment criteria and weightings (http://www.sustainability-index.com/07 htmle/assessment/criteria.html). (1) Governance: Codes of conduct/compliance/corruption and bribery (6\%), corporate governance (6\%), risk and crisis management (6\%), industry-specific criteria (by industry); (2) Environment: Environmental reporting assessed based on publicly available information (3\%), industry-specific criteria (by industry); (3) Social: Corporate citizenship/ philanthropy (3\%), labor practice indicators (5\%), human capital development (5.5\%), social reporting (3\%), talent attraction and retention (5.5\%), industry-specific criteria (by industry). The DJSI follows a best-in-class approach, ranking companies against their peers in 57 sectors, selecting the leading 10\% from the investable stocks universe of the 2,500 largest capitalized companies in the Dow Jones Global Total Stock Market Index. The index is reviewed annually; listed companies are monitored throughout the year to verify involvement in critical areas. To minimize excessive turnover, the process applies a "buffer rule" in which DJSI members need only to qualify amongst the best $13 \%$ to be retained, while new members need to be ranked in the best $7 \%$ in their industries.
} 
potentially biased source. Addition to the index, though, is a public act of CSR commitment because in addition to a voluntary action by the firm, it involves an independent and public audit; it is a signal to the market that the organization has fulfilled the ceremonial requirements of the institutionalized myths of inspection and evaluation (Espeland and Sauder 2007; Meyer and Rowan 1977; Sauder and Espeland 2009). Therefore, information about social status that comes from an independent third party such as the DJSI is credible in the market; moreover, by delineating a list of socially responsible firms, the index saves investors and analysts the costs associated with the search for information. Meyer and Rowan's (1977) notion of a ceremonial criteria of worth applies to additions to the DJSI, demonstrating an organization's social fitness and granting status to organizations with internal participants, stockholders, the public, the state, the IRS, and the SEC.

DJSI and Companies. Our archival review found that companies actively seek to be added to the DJSI for multiple reasons: to gain reputational and membership benefits, to seek insurance-like protection, to meet institutional pressures and stakeholder demands, to signal to analysts and investors that they are creating long-term shareholder value, to signify product and company differentiation, and to increase the value and recognition of the company's brand. Many executives believe that being listed on a socially responsible index will generate financial benefits from investors (who, in turn, expect the increased social status to attract support from major stakeholders, such as customers and regulators). A meta-analysis of CSR studies found modest financial returns to CSR (Margolis et al. 2007); however, few studies examined the economic impact of addition and deletion from a socially responsible index. As we argued above, addition to the socially responsible index demonstrates that firms have satisfied the expectations of social, political, and environmental counterparts and, moreover, have accomplished this in a visible and effective manner. Even if many of a firm's CSR activities might be known to market actors - and the current stock price might already reflect many of the expected benefits - validation by a credible third party such as the DJSI generates new information that has economic value.

DJSI and Analysts. In order to assess whether the DJSI generates meaningful information for investors, we conducted interviews with market analysts about the role of social indices in stock evaluation. We picked 16 additions to the DJSI, representing different industries. Using the One Source Database, we identified analyst reports that included stock valuation, company profile, recommendations, and analysis. We then contacted analysts involved in preparing these reports in several institutions, including Wachovia Capital Markets, Credit Suisse, HSBC, Deutsche Bank, Société Générale, Cowen and Company, Macquarie Research, CIBC World Markets, RBC Capital Markets, and Oppenheimer. We contacted 3 to 4 institutions per company, approaching analysts based in the U.S. and Europe. During 2009, we sent out 116 interview requests and were able to obtain 12 interviews (we can provide the interview protocol and transcriptions). More than half of the respondents were aware of the social indices, 
such as the DJSI, and used them or considered using them in their evaluations, supporting the assumption that the DJSI is a meaningful source of social status.

In turn, many of the respondents recommended contacting equities analysts that focus exclusively on socially responsible investing (SRI). An interview with an SRI analyst in France indicated that at least one third of all socially responsible investors rely on sustainability indexes in their decision-making. The other sources include sustainability reports, annual reports, press, industry association memberships, NGOs, and rating agencies; institutional investors were particularly likely to pay attention to the indices.

For exploratory reasons, we asked the analysts to comment on why the companies they cover would be added to a socially responsible index. The respondents identified four factors. First, the nature of the product: in some industries, the product itself can be considered socially responsible. The managed care company Humana, for instance, offered healthcare to minorities and disadvantaged people, which helped increase its share of Medicare business, thereby supporting the business case for CSR. Second, the nature of the industry: firms in the wireless equipment industry such as Motorola, for instance, can be considered "greener" than companies in other technology-related sector because radio waves do not affect human beings (according to current theories of science and physiology) and building wireless systems requires less physical infrastructure than any other type of construction. Third, company leadership: because CSR contributes to corporate reputation in the general merchandise industry (e.g., Wal-Mart, Target, and Carrefour), the former CEO of Wal-Mart, Lee Scott, reorganized the company's supplier structure by introducing more stringent requirements with the launch of the Wal-Mart Supplier Index. Wal-Mart's actions, in turn, initiated industry-wide change: for instance, Procter \& Gamble redesigned their laundry detergent, making it more concentrated, so that consumers could save water, producers could save plastic and energy, and distributors and retailers could save space. Finally, the industry life cycle can matter; for instance, in the past, analysts evaluated CSR issues in the utilities sector (e.g., firms such as EoN AG), but now they pay less attention to such issues because the practices are integrated within the utilities business and analysts pay attention to CSR news only when something goes wrong.

This multifaceted evaluation of the DJSI led us to conclude that the addition to (deletion from) the index is a credible and observable signal of social status, in terms of accomplishments in the area of CSR. Because many managers believe in the financial benefits of CSR, the evaluation of their social status by third parties provides a way to ascertain that a firm meets social norms and values. 


\section{APPENDIX B. Robustness check for selection into DJSI}

An additional robustness check verified that the DJSI adds and deletes companies based on their social - not financial performance. We constructed a new sample from several sources: 1) CSR performance from Thomson Reuters/Datastream (ASSET4, a Swiss-based company that specializes in providing objective, relevant, auditable, and systematic CSR information); 2) analyst coverage from I/B/E/S; and 3) accounting data from WorldScope. Our sample includes 10,584 observations based on 2,290 unique firms across 7 years (2002 to 2008) around the world; some specifications lose data due to the lag in some of our variables. The analysis investigates whether a firm's ROA or CSR drives DJSI addition or deletion. We ran two analyses (lagged and non-lagged variables) for two samples: 1) "Add-Full" and "Delete-Full" include all 2,290 firms; 2) "Add" and "Del" use only the DJSI firms, merged with the new data.

CSR is the weighted average of social, environmental, and governance scores for the focal firm for each year in our sample. ROA is the ratio of net income to total assets. Controls include: 1) Analyst Coverage measured as the number of analysts that cover a firm each year, to assess firm visibility; 2) Firm size measured as log of assets; 3) R\&D Intensity measured as ratio of R\&D expenses / sales; 4) Diversification measured as $\log$ of the number of four-digit SIC codes that a firm operates in each year; 5) SRI Index, an indicator of the existence or lack of a socially responsible market index in a given country to control for institutional country-level factors; 6) GDP per capita also addresses country factors; 7) Herfindahl index measured as the logged sum of squared ratios of firm sales over total industry sales in each year assesses industry dynamics. The regressions include year, country, and industry fixed effects. Standard errors (in parentheses) are robust to arbitrary heteroskedasticity and allow for serial correlation through firm-level clustering.

The results show a strong relationship between CSR and addition/deletion from DJSI. For ROA, by contrast, we find a negative relationship between ROA and deletions only in one case for deletions in the full sample (B.1b).

\begin{tabular}{|c|c|c|c|c|c|c|c|c|}
\hline & $\begin{array}{l}\text { B1a Add- } \\
\text { Full }\end{array}$ & $\begin{array}{l}\text { B1b Del- } \\
\text { Full }\end{array}$ & $\begin{array}{l}\text { B1c Add- } \\
\text { Full }\end{array}$ & $\begin{array}{l}\text { B1d Del- } \\
\text { Full }\end{array}$ & B2a Add & B2b Del & B2c Add & B2d Del \\
\hline \multirow[t]{2}{*}{ CSR } & $0.06^{* * * *}$ & $0.027 * * *$ & & & $0.491 * *$ & $-0.501 * *$ & & \\
\hline & $(0.008)$ & $(0.007)$ & & & $(0.202)$ & $(0.203)$ & & \\
\hline \multirow[t]{2}{*}{ ROA } & -0.0003 & $-0.0004 * *$ & & & -0.0002 & 0.0001 & & \\
\hline & $(0.0002)$ & $(0.0002)$ & & & $(0.005)$ & $(0.005)$ & & \\
\hline Analyst & 0.0002 & 0.0003 & & & -0.003 & 0.003 & & \\
\hline Coverage & $(0.0002)$ & $(0.0002)$ & & & $(0.004)$ & $(0.004)$ & & \\
\hline \multirow[t]{2}{*}{ Size } & $0.003^{* *}$ & $0.002 *$ & & & 0.017 & -0.017 & & \\
\hline & $(0.001)$ & $(0.001)$ & & & $(0.032)$ & $(0.032)$ & & \\
\hline \multirow[t]{2}{*}{ R\&D Intensity } & $3.87 \mathrm{E}-07$ & -0.0001 & & & 0.013 & -0.013 & & \\
\hline & $(0.0003)$ & $(0.0003)$ & & & $(0.013)$ & $(0.013)$ & & \\
\hline \multirow[t]{2}{*}{ Diversification } & -0.0007 & -0.003 & & & 0.008 & -0.007 & & \\
\hline & $(0.003)$ & $(0.003)$ & & & $(0.075)$ & $(0.075)$ & & \\
\hline \multirow[t]{2}{*}{ SRI Index } & -0.003 & -0.005 & 0.006 & -0.005 & 0.071 & -0.083 & 0.047 & -0.047 \\
\hline & $(0.011)$ & $(0.01)$ & $(0.014)$ & $(0.014)$ & $(0.193)$ & $(0.193)$ & $(0.29)$ & $(0.291)$ \\
\hline \multirow[t]{2}{*}{ Herfindahl } & 0.002 & 0.0008 & 0.003 & 0.003 & -0.01 & 0.011 & 0.0004 & -0.0004 \\
\hline & $(0.003)$ & $(0.002)$ & $(0.003)$ & $(0.003)$ & $(0.057)$ & $(0.057)$ & $(0.067)$ & $(0.067)$ \\
\hline GDP per capita & $\begin{array}{c}-6.75 \mathrm{e}-07 * * * \\
(2.20 \mathrm{E}-07)\end{array}$ & $\begin{array}{l}-2.53 \mathrm{E}-07 \\
(2.08 \mathrm{E}-07)\end{array}$ & $\begin{array}{c}-5.85 \mathrm{E}-06 \\
(5.26 \mathrm{E}-06)\end{array}$ & $\begin{array}{l}-1.66 \mathrm{E}-07 \\
(4.54 \mathrm{E}-07)\end{array}$ & $\begin{array}{c}-2.98 \mathrm{e}-05^{* * * *} \\
(7.59 \mathrm{E}-06)\end{array}$ & $\begin{array}{c}2.99 \mathrm{e}-05^{* * * *} \\
(7.60 \mathrm{E}-06)\end{array}$ & $\begin{array}{c}-2.95 \mathrm{e}-05^{* * *} \\
(9.64 \mathrm{E}-06)\end{array}$ & $\begin{array}{c}2.95 \mathrm{e}-05^{* * *} \\
(9.67 \mathrm{E}-06)\end{array}$ \\
\hline \multirow[t]{2}{*}{ Lagged CSR } & & & $0.065^{* * * *}$ & $\mathbf{0 . 0 3 9} * * *$ & & & 0.243 & -0.243 \\
\hline & & & $(0.009)$ & $(0.008)$ & & & $(0.272)$ & $(0.273)$ \\
\hline \multirow[t]{2}{*}{ Lagged ROA } & & & 0.0001 & $-6.79 \mathrm{E}-05$ & & & 0.005 & -0.005 \\
\hline & & & $(0.0002)$ & $(0.0002)$ & & & $(0.007)$ & $(0.006)$ \\
\hline Lagged Analyst & & & $-5.88 \mathrm{E}-05$ & $5.06 \mathrm{E}-05$ & & & -0.002 & 0.002 \\
\hline Coverage & & & $(0.0003)$ & $(0.0002)$ & & & $(0.005)$ & $(0.005)$ \\
\hline \multirow[t]{2}{*}{ Lagged Size } & & & $0.003 *$ & $0.003 * *$ & & & 0.004 & -0.004 \\
\hline & & & $(0.002)$ & $(0.001)$ & & & $(0.036)$ & $(0.036)$ \\
\hline Lagged R\&D & & & $1.55 \mathrm{E}-05$ & 0.0003 & & & -0.004 & 0.004 \\
\hline Intensity & & & $(0.0004)$ & $(0.0004)$ & & & $(0.013)$ & $(0.013)$ \\
\hline Lagged & & & -0.001 & -0.002 & & & -0.003 & 0.003 \\
\hline Diversification & & & $(0.004)$ & $(0.003)$ & & & $(0.087)$ & $(0.088)$ \\
\hline \multirow[t]{2}{*}{ Constant } & -0.027 & -0.016 & 0.161 & -0.033 & $1.25^{* * *}$ & -0.266 & $1.211^{* *}$ & -0.211 \\
\hline & $(0.017)$ & $(0.014)$ & $(0.193)$ & $(0.021)$ & $(0.446)$ & $(0.446)$ & $(0.505)$ & $(0.507)$ \\
\hline Observations & 10,584 & 10,584 & 8,291 & 8,291 & 366 & 368 & 285 & 287 \\
\hline No. of firms & 2,290 & 2,290 & 2,012 & 2,012 & 278 & 279 & 229 & 231 \\
\hline
\end{tabular}


APPENDIX C. OLS Estimates of the Impact of Addition and Deletion on Abnormal Returns Moderated by the Six Items of Current Firm Performance

\begin{tabular}{|c|c|c|c|c|c|c|c|c|c|c|c|c|}
\hline & \multicolumn{6}{|c|}{ H1: Addition to DJSI (Gain in Status) } & \multicolumn{6}{|c|}{ H2: Deletion from DJSI (Loss of Status) } \\
\hline & C1a & C1b & C1c & C1d & C1e & C1f & C2a & $\mathbf{C} 2 \mathbf{b}$ & C2c & C2d & C2e & C2f \\
\hline EBIT margin & $\begin{array}{l}-0.0298 * \\
(0.0165)\end{array}$ & & & & & & $\begin{array}{c}\mathbf{0 . 0 3 3 3} \\
(\mathbf{0 . 0 2 6 7 )}\end{array}$ & & & & & \\
\hline ECO margin & & $\begin{array}{l}-0.0104 \\
(0.0126)\end{array}$ & & & & & & $\begin{array}{l}\mathbf{0 . 0 3 3 0} * \\
(0.0175)\end{array}$ & & & & \\
\hline $\begin{array}{l}\text { Net income } \\
\text { margin (ROS) }\end{array}$ & & & $\begin{array}{l}-0.0084 \\
(0.0081)\end{array}$ & & & & & & $\begin{array}{c}0.0307 * * \\
(0.0124)\end{array}$ & & & \\
\hline ROA & & & & $\begin{array}{c}-0.0744 * * \\
(0.0338)\end{array}$ & & & & & & $\begin{array}{c}0.0410 \\
(0.0541)\end{array}$ & & \\
\hline ROC & & & & & $\begin{array}{c}-0.0458 * * \\
(0.0213)\end{array}$ & & & & & & $\begin{array}{c}0.0038 \\
(0.0093)\end{array}$ & \\
\hline ROE & & & & & & $\begin{array}{l}-0.009 * * \\
(0.0041)\end{array}$ & & & & & & $\begin{array}{c}0.0435 \\
(0.0367)\end{array}$ \\
\hline $\begin{array}{l}\text { Size (log of } \\
\text { employees) }\end{array}$ & $\begin{array}{c}-0.0037 * * * \\
(0.0014)\end{array}$ & $\begin{array}{c}-0.0035 * * * \\
(0.0013)\end{array}$ & $\begin{array}{c}-0.0036 * * * \\
(0.0013)\end{array}$ & $\begin{array}{l}-0.003 * * \\
(0.0014)\end{array}$ & $\begin{array}{l}-0.003 * * \\
(0.0015)\end{array}$ & $\begin{array}{c}-0.0036 * * * \\
(0.0014)\end{array}$ & & & & & & \\
\hline $\begin{array}{l}\text { Sector: Basic Res. } \\
\text { (v. Services) }\end{array}$ & $\begin{array}{l}-0.0076 \\
(0.0056)\end{array}$ & $\begin{array}{l}-0.0054 \\
(0.0053)\end{array}$ & $\begin{array}{l}-0.0052 \\
(0.0053)\end{array}$ & $\begin{array}{l}-0.0049 \\
(0.0054)\end{array}$ & $\begin{array}{l}-0.0081 \\
(0.0057)\end{array}$ & $\begin{array}{l}-0.0061 \\
(0.0054)\end{array}$ & $\begin{array}{l}0.0269 * * * \\
(0.0086)\end{array}$ & $\begin{array}{l}0.0231 * * * \\
(0.0082)\end{array}$ & $\begin{array}{c}0.0237 * * * \\
(0.0081)\end{array}$ & $\begin{array}{c}0.0194 * * \\
(0.0082)\end{array}$ & $\begin{array}{c}0.0197 * * \\
(0.0082)\end{array}$ & $\begin{array}{c}0.0274 * * * \\
(0.0087)\end{array}$ \\
\hline $\begin{array}{l}\text { Sector: Consumer } \\
\text { (v. Services) }\end{array}$ & $\begin{array}{c}-0.0089 * * \\
(0.0044)\end{array}$ & $\begin{array}{l}-0.0066 \\
(0.0041)\end{array}$ & $\begin{array}{l}-0.0063 \\
(0.0039)\end{array}$ & $\begin{array}{l}-0.0064 \\
(0.0040)\end{array}$ & $\begin{array}{c}-0.0091 * * \\
(0.0044)\end{array}$ & $\begin{array}{l}-0.0072 * \\
(0.0040)\end{array}$ & $\begin{array}{l}0.0133 * \\
(0.0067)\end{array}$ & $\begin{array}{c}0.0076 \\
(0.0059)\end{array}$ & $\begin{array}{c}0.0068 \\
(0.0057)\end{array}$ & $\begin{array}{c}0.0042 \\
(0.0059)\end{array}$ & $\begin{array}{c}0.0053 \\
(0.0059)\end{array}$ & $\begin{array}{l}0.0119 * \\
(0.0065)\end{array}$ \\
\hline $\begin{array}{l}\text { Sector: Industrial } \\
\text { (v. Services) }\end{array}$ & $\begin{array}{l}-0.0042 \\
(0.0058)\end{array}$ & $\begin{array}{l}-0.0014 \\
(0.0055)\end{array}$ & $\begin{array}{l}-0.0012 \\
(0.0054)\end{array}$ & $\begin{array}{l}-0.0012 \\
(0.0055)\end{array}$ & $\begin{array}{l}-0.0038 \\
(0.0058)\end{array}$ & $\begin{array}{c}0.0003 \\
(0.0056)\end{array}$ & $\begin{array}{c}0.0063 \\
(0.0078)\end{array}$ & $\begin{array}{c}0.0002 \\
(0.0071)\end{array}$ & $\begin{array}{c}-5.51 \mathrm{e}-06 \\
(0.0069)\end{array}$ & $\begin{array}{l}-0.0039 \\
(0.0072)\end{array}$ & $\begin{array}{l}-0.0033 \\
(0.0071)\end{array}$ & $\begin{array}{c}0.0032 \\
(0.0077)\end{array}$ \\
\hline $\begin{array}{l}\text { North America } \\
\text { (v. EU) }\end{array}$ & $\begin{array}{l}0.0006 \\
(0.004)\end{array}$ & $\begin{array}{c}0.0012 \\
(0.0038)\end{array}$ & $\begin{array}{c}0.0011 \\
(0.0038)\end{array}$ & $\begin{array}{c}0.0031 \\
(0.0038)\end{array}$ & $\begin{array}{c}0.0018 \\
(0.0041)\end{array}$ & $\begin{array}{c}0.0017 \\
(0.0038)\end{array}$ & $\begin{array}{c}0.0063 \\
(0.0063)\end{array}$ & $\begin{array}{c}0.0052 \\
(0.0058)\end{array}$ & $\begin{array}{c}0.0070 \\
(0.0058)\end{array}$ & $\begin{array}{c}0.0046 \\
(0.0061)\end{array}$ & $\begin{array}{c}0.0052 \\
(0.0061)\end{array}$ & $\begin{array}{c}0.0056 \\
(0.0065)\end{array}$ \\
\hline $\begin{array}{l}\text { Other Countries } \\
\text { (v. EU) }\end{array}$ & $\begin{array}{l}-0.0102 \\
(0.0076)\end{array}$ & $\begin{array}{l}-0.0109 \\
(0.0068)\end{array}$ & $\begin{array}{l}-0.0110 \\
(0.0068)\end{array}$ & $\begin{array}{l}-0.012 * \\
(0.007)\end{array}$ & $\begin{array}{l}-0.0119 \\
(0.0079)\end{array}$ & $\begin{array}{l}-0.0127 * \\
(0.0071)\end{array}$ & $\begin{array}{c}0.0016 \\
(0.0109)\end{array}$ & $\begin{array}{c}0.0015 \\
(0.0102)\end{array}$ & $\begin{array}{c}0.0025 \\
(0.0101)\end{array}$ & $\begin{array}{c}0.0015 \\
(0.0104)\end{array}$ & $\begin{array}{c}0.0019 \\
(0.0104)\end{array}$ & $\begin{array}{c}0.0015 \\
(0.0110)\end{array}$ \\
\hline $\begin{array}{l}\text { Negative press } \\
\text { past } 14 \text { months }\end{array}$ & $\begin{array}{c}0.0001 \\
(0.0007)\end{array}$ & $\begin{array}{c}-8.88 \mathrm{e}-05 \\
(0.0006)\end{array}$ & $\begin{array}{c}-8.38 \mathrm{e}-05 \\
(0.0006)\end{array}$ & $\begin{array}{l}-0.0003 \\
(0.0006)\end{array}$ & $\begin{array}{l}4.81 \mathrm{e}-05 \\
(0.0007)\end{array}$ & $\begin{array}{l}-0.0001 \\
(0.0006)\end{array}$ & $\begin{array}{l}-0.0004 \\
(0.0007)\end{array}$ & $\begin{array}{l}-0.0002 \\
(0.0007)\end{array}$ & $\begin{array}{l}-0.0002 \\
(0.0007)\end{array}$ & $\begin{array}{l}-0.00015 \\
(0.0007)\end{array}$ & $\begin{array}{l}-0.0002 \\
(0.0007)\end{array}$ & $\begin{array}{l}-0.0004 \\
(0.0007)\end{array}$ \\
\hline $\begin{array}{l}\text { Positive press } \\
\text { past } 14 \text { months }\end{array}$ & $\begin{array}{c}0.0011 \\
(0.0021)\end{array}$ & $\begin{array}{c}0.0012 \\
(0.0020)\end{array}$ & $\begin{array}{c}0.0012 \\
(0.0020)\end{array}$ & $\begin{array}{l}0.0017 \\
(0.002)\end{array}$ & $\begin{array}{c}0.0012 \\
(0.0021)\end{array}$ & $\begin{array}{c}0.0012 \\
(0.0020)\end{array}$ & $\begin{array}{c}0.0033 \\
(0.0027)\end{array}$ & $\begin{array}{c}0.0033 \\
(0.0026)\end{array}$ & $\begin{array}{c}0.0032 \\
(0.0026)\end{array}$ & $\begin{array}{c}0.0031 \\
(0.0027)\end{array}$ & $\begin{array}{c}0.0034 \\
(0.0031)\end{array}$ & $\begin{array}{c}0.0029 \\
(0.0027)\end{array}$ \\
\hline $\begin{array}{l}\text { Negative press } \\
1 \text { week before }\end{array}$ & $\begin{array}{l}-0.0016 \\
(0.0042)\end{array}$ & $\begin{array}{l}-0.0024 \\
(0.0040)\end{array}$ & $\begin{array}{l}-0.0025 \\
(0.0040)\end{array}$ & $\begin{array}{l}-0.0033 \\
(0.004)\end{array}$ & $\begin{array}{l}-0.0023 \\
(0.0043)\end{array}$ & $\begin{array}{l}-0.0026 \\
(0.0041)\end{array}$ & $\begin{array}{c}-0.009 * * * \\
(0.0023)\end{array}$ & $\begin{array}{c}-0.008 * * * \\
(0.0022)\end{array}$ & $\begin{array}{c}-0.008 * * * \\
(0.0022)\end{array}$ & $\begin{array}{c}-0.009 * * * \\
(0.0023)\end{array}$ & $\begin{array}{c}-0.009 * * * \\
(0.0023)\end{array}$ & $\begin{array}{c}-0.009 * * * \\
(0.0023)\end{array}$ \\
\hline $\begin{array}{l}\text { Positive press } \\
1 \text { week before }\end{array}$ & $\begin{array}{c}0.0041 \\
(0.0060)\end{array}$ & $\begin{array}{c}0.0046 \\
(0.0060)\end{array}$ & $\begin{array}{c}0.0047 \\
(0.0060)\end{array}$ & $\begin{array}{l}0.0048 \\
(0.006)\end{array}$ & $\begin{array}{c}0.0045 \\
(0.0062)\end{array}$ & $\begin{array}{c}0.0049 \\
(0.0061)\end{array}$ & $\begin{array}{c}0.0014 \\
(0.0037)\end{array}$ & $\begin{array}{c}-1.52 \mathrm{e}-05 \\
(0.0036)\end{array}$ & $\begin{array}{c}-6.89 \mathrm{e}-05 \\
(0.0035)\end{array}$ & $\begin{array}{l}-0.0005 \\
(0.0036)\end{array}$ & $\begin{array}{l}-0.0004 \\
(0.0036)\end{array}$ & $\begin{array}{c}0.0009 \\
(0.0037)\end{array}$ \\
\hline Constant & $\begin{array}{c}0.0456^{* * *} \\
(0.0151)\end{array}$ & $\begin{array}{c}0.0386^{* * * *} \\
(0.0142)\end{array}$ & $\begin{array}{c}0.0387 * * * \\
(0.0142)\end{array}$ & $\begin{array}{c}0.0376 * * \\
(0.0145)\end{array}$ & $\begin{array}{l}0.04 * * * \\
(0.0152)\end{array}$ & $\begin{array}{l}0.04 * * * \\
(0.0146)\end{array}$ & $\begin{array}{c}-0.0236 * * * \\
(0.0088)\end{array}$ & $\begin{array}{c}-0.0156 * * \\
(0.0069)\end{array}$ & $\begin{array}{c}-0.0164 * * \\
(0.0067)\end{array}$ & $\begin{array}{l}-0.0117 * \\
(0.0069)\end{array}$ & $\begin{array}{l}-0.011 * \\
(0.0067)\end{array}$ & $\begin{array}{l}-0.02 * * * \\
(0.0077)\end{array}$ \\
\hline Observations & 241 & 266 & 266 & 265 & 240 & 265 & 137 & 150 & 150 & 147 & 146 & 134 \\
\hline R-squared & 0.078 & 0.065 & 0.066 & 0.083 & 0.088 & 0.083 & 0.220 & 0.201 & 0.215 & 0.185 & 0.181 & 0.222 \\
\hline
\end{tabular}


APPENDIX D. Robustness Tests

\begin{tabular}{|c|c|c|c|c|c|c|}
\hline & $\begin{array}{l}\text { H1: Add } \\
\text { D1a }\end{array}$ & $\begin{array}{l}\text { H1: Add } \\
\text { D1b }\end{array}$ & $\begin{array}{l}\text { H2: Delete } \\
\text { D2a } \\
\end{array}$ & $\begin{array}{c}\text { H2: Delete } \\
\text { D2b }\end{array}$ & $\begin{array}{l}\text { H2: Delete } \\
\text { D3a } \\
\end{array}$ & $\begin{array}{l}\text { H2: Delete } \\
\text { D3b } \\
\end{array}$ \\
\hline Current Firm Performance & $\begin{array}{l}-0.0164 * \\
(0.0106)\end{array}$ & $\begin{array}{c}-0.0247 * * \\
(0.0098)\end{array}$ & $\begin{array}{l}0.0378 * \\
(0.0217)\end{array}$ & $\begin{array}{l}0.0561 * * \\
(0.0216)\end{array}$ & $\begin{array}{l}0.0066 * \\
(0.0035)\end{array}$ & $\begin{array}{c}0.0069 * * \\
(0.0034)\end{array}$ \\
\hline Expected Firm Performance & $\begin{array}{l}-0.0049 * \\
(0.0025)\end{array}$ & $\begin{array}{c}-0.0053 * * \\
(0.0024)\end{array}$ & $\begin{array}{l}0.0072 * \\
(0.0046)\end{array}$ & $\begin{array}{l}0.0062 * \\
(0.0035)\end{array}$ & $\begin{array}{l}0.0396 * \\
(0.0205)\end{array}$ & $\begin{array}{l}0.0387 * \\
(0.0203)\end{array}$ \\
\hline $\begin{array}{l}\text { Slack Resources (current } \\
\text { liabilities /current assets) }\end{array}$ & $\begin{array}{c}0.0018 \\
(0.0050)\end{array}$ & & $\begin{array}{l}-0.0085 \\
(0.0076)\end{array}$ & & & \\
\hline Age & & $\begin{array}{c}2.74 \mathrm{e}-05 \\
(3.54 \mathrm{e}-05)\end{array}$ & & $\begin{array}{c}6.18 \mathrm{e}-06 \\
(5.11 \mathrm{e}-05)\end{array}$ & & \\
\hline Vertical Diversification & & $\begin{array}{c}0.0002 \\
(0.0003)\end{array}$ & & $\begin{array}{l}0.0005 \\
(0.0004)\end{array}$ & & \\
\hline Horizontal Diversification & & $\begin{array}{c}0.0005 \\
(0.0023)\end{array}$ & & $\begin{array}{l}-0.0028 \\
(0.0035)\end{array}$ & & \\
\hline $\mathrm{R} \& \mathrm{D}$ & & $\begin{array}{l}-0.0001 * * * \\
(3.83 \mathrm{e}-05)\end{array}$ & & $\begin{array}{c}9.22 \mathrm{e}-05 \\
(5.59 \mathrm{e}-05)\end{array}$ & & \\
\hline Advertising & & $\begin{array}{l}-6.75 e-07 \\
(4.08 \mathrm{e}-06)\end{array}$ & & $\begin{array}{c}-1.37 \mathrm{e}-05^{* *} \\
(6.12 \mathrm{e}-06)\end{array}$ & & \\
\hline Size (log of employees) & $\begin{array}{l}-0.0019 \\
(0.0015)\end{array}$ & $\begin{array}{c}-0.0035 * * \\
(0.0014)\end{array}$ & & & $\begin{array}{l}-0.0022 \\
(0.0019)\end{array}$ & $\begin{array}{c}-0.0013 * * \\
(0.0006)\end{array}$ \\
\hline $\begin{array}{l}\text { Sector: Basic Resources } \\
\text { (v. Services) }\end{array}$ & $\begin{array}{c}-0.0130 * * \\
(0.0059)\end{array}$ & $\begin{array}{l}-0.0034 \\
(0.0078)\end{array}$ & $\begin{array}{c}0.0261 * * \\
(0.0112)\end{array}$ & $\begin{array}{l}-0.0719 \\
(0.0456)\end{array}$ & $\begin{array}{l}0.0210 * * \\
(0.0081)\end{array}$ & $\begin{array}{c}0.0219 * * * \\
(0.0079)\end{array}$ \\
\hline $\begin{array}{l}\text { Sector: Consumer } \\
\text { (v. Services) }\end{array}$ & $\begin{array}{l}-0.0083^{*} \\
(0.0045)\end{array}$ & $\begin{array}{c}-0.0161 * * * \\
(0.0053)\end{array}$ & $\begin{array}{c}0.0074 \\
(0.0073)\end{array}$ & $\begin{array}{l}-0.0769 * \\
(0.0420)\end{array}$ & $\begin{array}{c}0.0065 \\
(0.0059)\end{array}$ & $\begin{array}{c}0.0065 \\
(0.0059)\end{array}$ \\
\hline $\begin{array}{l}\text { Sector: Industrial } \\
\text { (v. Services) }\end{array}$ & $\begin{array}{l}-0.0055 \\
(0.0058)\end{array}$ & $\begin{array}{l}-0.0028 \\
(0.0065)\end{array}$ & $\begin{array}{c}0.0033 \\
(0.0087)\end{array}$ & $\begin{array}{c}-0.0946^{* *} \\
(0.0442)\end{array}$ & $\begin{array}{l}-0.0014 \\
(0.0069)\end{array}$ & $\begin{array}{l}-0.0011 \\
(0.0068)\end{array}$ \\
\hline $\begin{array}{l}\text { Headquarters: North America } \\
\text { (v. EU) }\end{array}$ & $\begin{array}{c}0.0030 \\
(0.0042)\end{array}$ & $\begin{array}{c}0.0038 \\
(0.0038)\end{array}$ & $\begin{array}{c}0.0071 \\
(0.0069)\end{array}$ & $\begin{array}{c}0.0057 \\
(0.0059)\end{array}$ & $\begin{array}{c}0.0049 \\
(0.0059)\end{array}$ & $\begin{array}{c}0.0061 \\
(0.0055)\end{array}$ \\
\hline $\begin{array}{l}\text { Headquarters: Other Countries } \\
\text { (v. EU) }\end{array}$ & $\begin{array}{l}-0.0085 \\
(0.0076)\end{array}$ & $\begin{array}{l}-0.0115^{*} \\
(0.0068)\end{array}$ & $\begin{array}{c}0.001 \\
(0.0119)\end{array}$ & $\begin{array}{c}-0.001 \\
(0.0102)\end{array}$ & $\begin{array}{c}0.0035 \\
(0.0101)\end{array}$ & $\begin{array}{c}0.0038 \\
(0.0101)\end{array}$ \\
\hline Negative press: Past 14 months & $\begin{array}{l}4.32 \mathrm{e}-05 \\
(0.0007)\end{array}$ & $\begin{array}{l}-0.0003 \\
(0.0006)\end{array}$ & $\begin{array}{c}0.0004 \\
(0.0009)\end{array}$ & $\begin{array}{l}-0.0007 \\
(0.0007)\end{array}$ & $\begin{array}{c}-4.05 \mathrm{e}-05 \\
(0.0007)\end{array}$ & $\begin{array}{c}-8.86 \mathrm{e}-05 \\
(0.0007)\end{array}$ \\
\hline Positive press: Past 14 months & $\begin{array}{c}0.0016 \\
(0.0020)\end{array}$ & $\begin{array}{c}0.0009 \\
(0.0020)\end{array}$ & $\begin{array}{l}-0.0049 \\
(0.0051)\end{array}$ & $\begin{array}{l}0.0087 * * \\
(0.0034)\end{array}$ & $\begin{array}{c}0.0044 \\
(0.0027)\end{array}$ & $\begin{array}{c}0.0042 \\
(0.0026)\end{array}$ \\
\hline Negative press: 1 week before & $\begin{array}{l}-0.0029 \\
(0.0041)\end{array}$ & $\begin{array}{l}-0.0039 \\
(0.0041)\end{array}$ & $\begin{array}{c}-0.0085 * * * \\
(0.0027)\end{array}$ & $\begin{array}{c}-0.0078 * * * \\
(0.0022)\end{array}$ & $\begin{array}{c}-0.0079 * * * \\
(0.0022)\end{array}$ & $\begin{array}{c}-0.0079 * * * \\
(0.0022)\end{array}$ \\
\hline Positive press: 1 week before & $\begin{array}{c}0.0095 \\
(0.0065)\end{array}$ & $\begin{array}{l}0.0051 \\
(0.006)\end{array}$ & $\begin{array}{l}-0.0002 \\
(0.0064)\end{array}$ & $\begin{array}{l}-0.0006 \\
(0.0035)\end{array}$ & $\begin{array}{c}0.0007 \\
(0.0036)\end{array}$ & $\begin{array}{c}0.0004 \\
(0.0035)\end{array}$ \\
\hline Constant & $\begin{array}{c}0.0199 \\
(0.0171)\end{array}$ & $\begin{array}{l}0.0286 * \\
(0.0152)\end{array}$ & $\begin{array}{l}-0.0085 \\
(0.0110)\end{array}$ & $\begin{array}{l}0.0838 * \\
(0.0471)\end{array}$ & $\begin{array}{c}0.0102 \\
(0.0205)\end{array}$ & \\
\hline Observations & 203 & 267 & 113 & 150 & 150 & 150 \\
\hline R-squared & 0.094 & 0.145 & 0.215 & 0.264 & 0.227 & 0.242 \\
\hline
\end{tabular}

Note: Control variables for other measures of slack resources (e.g., total liabilities/total assets), for membership in highly regulated industries (Cho and Patten 2007) were insignificant. 